\title{
Novel Cre-Expressing Mouse Strains Permitting to Selectively Track and Edit Type 1 Conventional Dendritic Cells Facilitate Disentangling Their Complexity in vivo
}

\author{
Raphaël Mattiuz ${ }^{1}$, Christian Wohn ${ }^{1}$, Sonia Ghilas ${ }^{1}$, Marc Ambrosini ${ }^{1}$, \\ Yannick O. Alexandre ${ }^{1}$, Cindy Sanchez ${ }^{1}$, Anissa Fries ${ }^{1}$, Thien-Phong Vu Manh ${ }^{1}$, \\ Bernard Malissen ${ }^{1,2}$, Marc Dalod ${ }^{1 *}$ and Karine Crozat ${ }^{1 *}$ \\ ${ }^{1}$ Centre d'Immunologie de Marseille-Luminy, Turing Center for Living Systems, CNRS, INSERM, Aix Marseille Univ, Marseille, \\ France, ${ }^{2}$ Centre d'Immunophénomique, Aix Marseille Univ, CNRS, INSERM, Marseille, France
}

OPEN ACCESS

Edited by:

Diana Dudziak

Universitätsklinikum Erlangen

Germany

Reviewed by:

Natalio Garbi,

Universität Bonn, Germany

Christophe Jean Desmet,

University of Liege, Belgium

*Correspondence: Marc Dalod

dalod@ciml.univ-mrs.fr Karine Crozat

crozat@ciml.univ-mrs.fr

Specialty section:

This article was submitted to Antigen Presenting Cell Biology,

a section of the journal

Frontiers in Immunology

Received: 29 July 2018 Accepted: 14 November 2018 Published: 04 December 2018

Citation:

Mattiuz R, Wohn C, Ghilas S,

Ambrosini $M$, Alexandre YO, Sanchez C, Fries A, Vu Manh T-P, Malissen B, Dalod M and Crozat $K$ (2018) Novel Cre-Expressing Mouse Strains Permitting to Selectively Track

and Edit Type 1 Conventional Dendritic Cells Facilitate Disentangling Their Complexity in vivo.

Front. Immunol. 9:2805.

doi: 10.3389/fimmu.2018.02805
Type 1 conventional DCs (cDC1) excel in the cross-priming of $\mathrm{CD}^{+} \mathrm{T}$ cells, which is crucial for orchestrating efficient immune responses against viruses or tumors. However, our understanding of their physiological functions and molecular regulation has been limited by the lack of proper mutant mouse models allowing their conditional genetic targeting. Because the Xcr1 and A530099j19rik (Karma/Gpr141b) genes belong to the core transcriptomic fingerprint of mouse $\mathrm{CDC1}$, we used them to engineer two novel Cre-driver lines, the $\mathrm{X}_{\mathrm{Cr}}{ }^{\mathrm{Cre}}$ and $\mathrm{Karma}{ }^{\mathrm{Cre}}$ mice, by knocking in an IRES-Cre expression cassette into their $3^{\prime}$-UTR. We used genetic tracing to characterize the specificity and efficiency of these new models in several lymphoid and non-lymphoid tissues, and compared them to the $\mathrm{Clec9aCre}$ mouse model, which targets the immediate precursors of cDCs. Amongst the three Cre-driver mouse models examined, the $\mathrm{X}_{\mathrm{Cr}}{ }^{\mathrm{Cre}}$ model was the most efficient and specific for the fate mapping of all $\mathrm{CDC1}$, regardless of the tissues examined. The KarmaCre model was rather specific for $\mathrm{CDC} 1$ when compared with the $\mathrm{ClecOa}^{\mathrm{Cre}}$ mouse, but less efficient than the $\mathrm{XCr}^{\mathrm{Cre}}$ model. Unexpectedly, the $\mathrm{X}_{\mathrm{Cr}}{ }^{\mathrm{Cre}}$ model targeted a small fraction of $\mathrm{CD} 4^{+} \mathrm{T}$ cells, and the KarmaCre model a significant proportion of mast cells in the skin. Importantly, the targeting specificity of these two mouse models was not changed upon inflammation. A high frequency of germline recombination was observed solely in the $\mathrm{XCr}{ }^{\mathrm{Cre}}$ mouse model when both the Cre and the floxed alleles were brought by the same gamete irrespective of its gender. Xcr1, Karma, and Clec9a being differentially expressed within the CDC1 population, the three CRE-driver lines examined showed distinct recombination patterns in CDC1 phenotypic subsets. This advances our understanding of CDC1 subset heterogeneity and the differentiation trajectory of these cells. Therefore, to the best of our knowledge, upon informed use, the $\mathrm{X}_{\mathrm{Cr}}{ }^{\mathrm{Cre}}$ and $\mathrm{KarmaCre}$ mouse models represent the best tools currently reported to specifically and faithfully target $\mathrm{CDC} 1$ in vivo, both at steady state and upon inflammation. Future use of these mutant mouse models will undoubtedly boost our understanding of the biology of cDC1.

Keywords: dendritic cells, cDC1, XCR1, Gp141b, Karma, Clec9a, Cre, fate mapping 


\section{INTRODUCTION}

Dendritic cells (DCs) constitute a heterogeneous population of antigen presenting cells (APCs) which are instrumental for the orchestration of innate and adaptive immune responses. In mice and in humans, three distinct types of DCs differing in their phenotype, localization and functions populate all lymphoid and most non-lymphoid tissues at steady state. Plasmacytoid DCs (pDCs) are the major source of type I interferon (IFN) upon many viral infections. Conventional DCs (cDCs) consist of two populations, coined as type 1 and type $2 \mathrm{cDCs}$ and which excel in the cross-priming of $\mathrm{CD}^{+} \mathrm{T}$ cells or in the promotion of $\mathrm{CD}^{+} \mathrm{T}$ cell and humoral immunity, respectively. The functions of $\mathrm{cDCs}$ and their molecular regulation have been studied in vivo by using a wealth of mouse models that enable their depletion or genetic manipulation, namely $C d 11 \mathrm{c}$ $(\operatorname{Itgax})^{h D T R}(1)$ or Cd11c (Itgax) Cre $(2,3)$ and more recently the $Z b t b 46^{h D T R}$ (4) or Zbtb46 Cre (5). However, interpretation of the results obtained using those mice can be difficult due to the expression of Cd11c by many other cell types than $\mathrm{cDCs}$ and of Zbtb46 by committed erythroid progenitors and endothelial cell populations (6). Moreover, these mutant mouse models are not suited to study the respective functions of each of the two cDC types. This goal requires the use of refined mutant mouse models enabling specific targeting of either $\mathrm{CDC} 1$ or $\mathrm{CDC} 2$.

Constitutive (Batf3-KO mice) or conditional (Itgax ${ }^{\mathrm{Cre}} ; \operatorname{Irf} 8^{f l / f l}$ mice) genetic inactivation of transcription factors required for the differentiation of $\mathrm{cDC1}$ allowed to study their specific functions in vivo $(7,8)$. However, interpretation of the results obtained with these models can be difficult because they are not targeting solely $\mathrm{cDC1}(7,9-11)$. Moreover, $\mathrm{CDC} 1$ are replenished in Batf3-KO mice under inflammatory conditions, due to expression of other Batf transcription factors that compensate for Batf3 loss (12). Finally, these models do not allow the editing of cDC1 genome, which would be a powerful method to decipher the molecular regulation of their functions. Hence, novel mutant mouse models are needed to reach this goal.

In all tissues with the exception of the intestine, $\mathrm{CDC1}$ can be defined as $\mathrm{CD} 24^{+}$SIRP $\alpha / C D 172 \mathrm{a}^{-}$cDCs (13-15). In addition, lymphoid-tissue resident $\mathrm{CDC} 1$ express $\mathrm{CD} 8 \alpha$, whereas the $\mathrm{CDC} 1$ residing in the parenchyma of non-lymphoid tissues and their counterparts that have migrated in secondary lymphoid organs express CD103. CLEC9A, a C type lectin receptor that allows efficient cross-presentation by $\mathrm{cDC} 1$ of dying cell-associated antigens (16) has been identified as a good candidate to generate mice enabling selective targeting of $\mathrm{CDC1}$ in vivo due to its selective expression in these cells and to a lesser extent in pDCs (17-20). However, a thorough analysis of mice expressing a Cre recombinase under the Clec $9 a$ promoter showed that Cre-driven recombination occurred not only in $\mathrm{CDC1}$ and to some extent in pDCs, but also in $\mathrm{cDC} 2$, leading to the discovery that $\operatorname{Clec} 9 a$ is expressed in a progenitor cell common to both cDC types (21). Hence, the Clec $9 a^{C r e}$ mouse is not suitable for specific targeting of $\mathrm{CDC} 1$.

A major breakthrough in the field of $\mathrm{CDC1}$ was the identification of XCR1 as a universal marker of all cDC1 regardless of their tissues of residency, and present in all the warm-blooded vertebrate species studied to date (22-27). Xcr1 encodes the chemokine receptor XCR1, which ligand XCL1 is strongly upregulated in natural killer $(\mathrm{NK})$ cells, $\mathrm{CD}^{+} \mathrm{T}$ cells and memory $\mathrm{T}$ cells upon activation in mice $(24,26,28-31)$. Recently, a mouse model based on the expression of the Cre recombinase under the control of the Xcrl promoter has been generated to specifically manipulate gene expression in $\mathrm{CDC} 1$. This mutant mouse model was engineered by replacing the single coding exon of Xcrl by the Cre gene (32). This strategy assumes that the Xcrl gene is haplosufficient. However, this hypothesis has to be tested considering that XCR1 promotes the crosstalk between $\mathrm{cDC} 1$ and NK cells or $\mathrm{CD} 8^{+} \mathrm{T}$ lymphocytes, by facilitating their reciprocal recruitment and/or activation (24, 26, 29). Regardless of its potential limitation, this $\mathrm{Xcr}^{\text {tm } 4 \text { (cre)Ksho }}$ mouse model has been useful to decipher the role of $\mathrm{cDC1}$ in intraepithelial $\mathrm{T}$ cell homeostasis in the intestine (32). However, to the best of our knowledge, it has not been used yet for conditional gene targeting of the $\mathrm{CDC1}$ lineage. Besides Xcrl, the A530099j19rik gene (named Karma hereafter) has also been identified as selectively expressed in $\mathrm{cDC1}$ by bulk transcriptomic analysis on immune cell subsets and organs (10, 33). The Karma gene encodes a protein with 7 transmembrane domains, likely corresponding to a $G$ protein-coupled receptor, leading to its recent denomination as Gpr141b by the Mouse Genome Informatics. Recently, we generated the Karma knockin reporter/deleter mouse model, which expresses in the Karma locus a construct encoding both the fluorescent tandem dimer Tomato (tdTomato) and the human diphtheria toxin receptor (hDTR), allowing specific tracking and conditional depletion of $\mathrm{CDC1}$ in vivo. Results obtained with this reporter mouse validated the Karma locus as highly reliable to functionally target $\mathrm{CDC} 1$ in vivo (33).

To match the unmet need of a mouse model allowing specific and efficient in vivo genetic manipulation of $\mathrm{CDC1}$, we generated two novel Cre-driver lines, the $\mathrm{Xcrl}^{\mathrm{Cre}}$ and $\mathrm{Karma}^{\mathrm{Cre}}$ mice, by knocking in an IRES-Cre expression cassette in the $3^{\prime}$-UTR of the Xcr1 or Karma locus, respectively. In this study, we used genetic tracing to characterize the specificity and efficiency of the Cre-mediated recombination in these new models at steady state and upon infection, and compared them with the $\mathrm{Clec} 9 a^{\mathrm{Cre}}$ model. This study also advanced our understanding of the phenotypic heterogeneity of $\mathrm{cDC} 1$ with regard to their differentiation trajectory.

\section{MATERIALS AND METHODS Generation of CDC1 Targeting Cre Constructs and Mice}

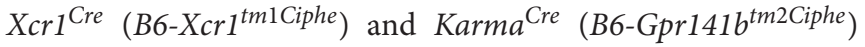
mice were made according to a standard gene targeting approach in C57BL/6N-derived ES cells. They were constructed by inserting, through ET homologous recombination, a cassette containing the internal ribosome entry site (IRES) followed by a gene encoding the codon-improved version of Cre recombinase (34), into the $3^{\prime}$-UTR of the Xcr1 or A530099j19rik/Gpr141b genes, 34 and $98 \mathrm{bp}$ after the stop codon, respectively. These 
mice were outcrossed for three generations with wild type (Wt) C57BL/6J mice purchased from Charles River Laboratories. All experiments were performed with sex-matched littermate mice at 6-12 weeks of age. Clec9aCre $\left(\right.$ Clec $\left.9 a^{\text {tm2.1(icre)Crs }}\right)$ (21) knock-in mice [kindly provided by Caetano Reis e Sousa (The Francis Crick Institute, UK)], Karma-tdTomato-hDTR $\left(G p 141 b^{\text {tm1Ciphe }}\right)$ (33) were maintained on the C57BL/6J background. Rosa26 lox-stop-lox-tdRFP (Gt(ROSA)26Sor ${ }^{\text {tm } 1 \mathrm{Hjf}}$ ) mice in which expression of the tandem dimer Red Fluorescent Protein (tdRFP) is driven through the deletion of a "loxstop-lox" sequence (35) were purchased from the Jackson Laboratory and maintained on the C57BL/6J background. Rosa26 $^{\text {lox-stop-lox-DTA }}\left(\right.$ Gt $(R O S A) 26$ Sor $\left.^{\text {tm1 } 1(D T A) L k y}\right)$ mice in which expression of active domain of the diphtheria toxin (DTA) is driven through the deletion of a "lox-stop-lox" sequence (36) were obtained from Prs. David Voehringer and Richard M. Locksley, and maintained on the C57BL/6J background. Mice were bred and maintained in our specific pathogen-free animal facility. This study was carried out in accordance with institutional guidelines and with protocols approved by the Comité National de Réflexion Ethique sur l'Expérimentation Animale \#14.

\section{Preparation of Cell Suspension From Blood and Tissues, and Analysis by Flow Cytometry}

Splenocytes were prepared by infusing spleens with an enzymatic cocktail made of Collagenase D $(1 \mathrm{mg} / \mathrm{ml})$ and DNase I $(70 \mu \mathrm{g} / \mathrm{ml}$, both Roche) in plain RPMI 1640, and further incubation for $25 \mathrm{~min}$ at $37^{\circ} \mathrm{C}$. Ice cold EDTA $(2 \mathrm{mM})$ was added for additional $5 \mathrm{~min}$. Cells were filtered through a $70-\mu \mathrm{m}$ nylon sieve, and exposed to $0.155 \mathrm{M} \mathrm{NH} 4 \mathrm{Cl}, 10 \mathrm{mM} \mathrm{KHCO}_{3}$, $0.127 \mathrm{M}$ EDTA to lyse red blood cells. Liver and lungs were minced in an enzymatic cocktail $(1 \mathrm{mg} / \mathrm{ml}$ of Collagenase $\mathrm{D}$ and $70 \mu \mathrm{g} / \mathrm{ml}$ of DNase I), incubated for $25 \mathrm{~min}$ at $37^{\circ} \mathrm{C}$. Ice-cold EDTA $(2 \mathrm{mM})$ was added for additional $5 \mathrm{~min}$, then digested tissues were filtered through a $70 \mu \mathrm{m}$ nylon sieve (BD Falcon). Low-density cells were further enriched by centrifugation over a $1.069 \mathrm{~g} / \mathrm{ml}$ density gradient (OptiPrep, Axis-Shield), washed and resuspended in PBS, EDTA $2 \mathrm{mM}, 2 \%$ BSA, and red blood cells were lysed as detailed above. Cutaneous LNs (inguinal and axillar LNs) were cut into small pieces and digested for $25 \mathrm{~min}$ at $37^{\circ} \mathrm{C}$ with a mixture of type II collagenase (Worthington Biochemical) and DNase I (Sigma-Aldrich) in plain RPMI 1640. The resulting cell suspension was treated with $5 \mathrm{mM}$ EDTA and filtered through a $70 \mu \mathrm{m}$ nylon sieve (BD Falcon). For the skin, ears were split into a ventral and dorsal parts and incubated for $105 \mathrm{~min}$ at $37^{\circ} \mathrm{C}$ in RPMI containing $0.25 \mathrm{mg} / \mathrm{ml}$ Liberase TL (Roche Diagnostic Corp.) and $0.5 \mathrm{mg} / \mathrm{ml}$ DNase I (Sigma Aldrich). Digested tissue was homogenized using Medicons and Medimachine (Becton Dickinson) to obtain homogenous cell suspensions. For skin mast cells, we used a protocol recently described (37). To test the germline recombination in blood cells, peripheral blood mononuclear cells (PBMCs) were enriched by centrifugation over a $1.077 \mathrm{~g} / \mathrm{ml}$ density gradient (FicollPaque Plus, GE Healthcare), washed and resuspended in PBS,
EDTA 2 mM, 2\% BSA before staining. Staining of cells for flow cytometry started with a pre-incubation with $2.4 \mathrm{G} 2 \mathrm{mAb}$ to block unspecific binding to Fc-receptors. Staining with mAb (Supplementay Table S1) was then performed in PBS, 2\% BSA, $2 \mathrm{mM}$ EDTA for $25 \mathrm{~min}$ on ice. For exclusion of dead cells 4',6-diamidino-2-phenylindole (DAPI, Thermo Fisher Scientific) was added $5 \mathrm{~min}$ before acquisition. Data were acquired on a LSRFortessa X-20 flow cytometer (BD Biosciences), and analyzed using FlowJo (Tree Star, Inc.).

\section{Bone Marrow-Derived DC Differentiation}

FLT3-L-BMDCs were generated as described (38) with some modifications. BM cell suspensions were prepared and red blood cells were lysed as detailed in the previous section. After washing in complete RPMI 1640 medium, cells were cultured at $3 \times 10^{6}$ cells/ml in 24 well plates, with 10\% FBS, RPMI 1640 medium containing murine FLT3-L (in house supernatant from B16-Flt3l cells, used at $1 / 20$ final) at $37^{\circ} \mathrm{C}$ in $5 \% \mathrm{CO} 2$. Four days after, half of the culture medium was replaced by fresh FLT3-L. Cells were harvested at indicated times for flow cytometry analysis after staining for CD11c, SiglecH, CD24, SIRP $\alpha, \mathrm{XCR} 1$, and CD11b (Supplementay Table S1).

\section{Microarray Data Generation and Analysis}

DCs were generated in vitro from mouse BM FLT3-L cultures and sorting by flow cytometry to over $98 \%$ purity, as live, singlet, $\mathrm{CD}_{11 c^{+}}$cells that were SiglecH ${ }^{+}$for eq-pDCs, $\mathrm{SIRP} \alpha^{-} \mathrm{CD} 24^{\text {high }}$ for eq-cDC1 and SIRP $\alpha^{+} \mathrm{CD} 24^{-/ \text {low }}$ for eq-cDC2. Total RNA (50 ng) was used as starting material for each sample to synthesize biotinylated probes, using the NuGen protocol as described previously (39). Affymetrix Mouse Gene 1.0 ST raw. CEL files were analyzed in the $\mathrm{R}$ statistical environment (version 3.4.1). Data were RMA normalized using the oligo package and processed as described previously (40). Heatmaps of Log2normalized expression values of selected genes were performed using the Morpheus website from the Broad Institute (https:// software.broadinstitute.org/morpheus/). Hierarchical clusterings were performed using the One-Pearson correlation as a metric and the average linkage as a clustering method for samples and genes, except for Figure 5B where the complete linkage method was used for the genes. The microarray data have been deposited in the GEO database under the series accession number GSE121859.

\section{Mouse Cytomegalovirus Infection}

Animals were infected intraperitoneally with $2 \times 10^{5} \mathrm{PFU}$ of salivary gland-extracted MCMV Smith strain (3rd in vivo passage). Forty-Eight hours later, spleen and liver were harvested and prepared for flow cytometry analysis as described above.

\section{Analysis of Germline Recombination}

Four females and 2 males of each Xcr1 ${ }^{C r e / w t}$; Rosa26 $6^{\text {tdRFP/wt }}$ and $\mathrm{Karma} \mathrm{Cre}^{\mathrm{w} t}$; Rosa26 $6^{\text {tdRFP/wt }}$ genotype were backcrossed to $\mathrm{C} 57 \mathrm{BL} / 6 \mathrm{~J}$ mice. Their progeny was genotyped and bled to analyse tdRFP expression in circulating $\mathrm{T}$ and $\mathrm{B}$ cells as a sign of germline recombination. 


\section{RESULTS}

\section{Generation of New cDC1-Targeting Cre-Driver Lines}

By comparative gene expression profiling, we and other have previously identified Xcr1 and a530099j19rik (Gpr141b/Karma) genes as specifically expressed by mouse $\mathrm{CDC} 1$ in different tissues throughout the body $(10,22-26,31,33)$. We used such unique gene expression profile to genetically target $\mathrm{CDC} 1$ in vivo by generating $\mathrm{Xcrl}^{\mathrm{Cre}}$ (Figure 1A) and Karma Cre (Figure 1B) knock-in mouse models. The insertion of an IRES-Cre cassette after the STOP codon of Xcr1 and Karma genes allows the translation of two separate proteins resulting in the expression of the Cre recombinase. Expression of endogenous XCR1 was not significantly altered in the $\mathrm{Xcr} 1^{\mathrm{Cre}}$ mouse model (Supplementary Figure S1A, top).

\section{The XCR1 Cre Mouse Model Allows Selective and Efficient Recombination of loxP Sequences in Migratory and Resident cDC1 in All Tissues Examined}

To determine the specificity of the Cre-induced recombination in $\mathrm{Xcrl}^{\mathrm{Cre}}$ (Figure 1A) and Karma ${ }^{\mathrm{Cre}}$ (Figure 1B) mice, we bred them with the Cre-reporter line Rosa26 lox-stop-lox-tdRFP (named hereafter Rosa26 ${ }^{\text {tdRFP }}$ ) (35), and analyzed the tdRFP expression pattern in immune cells of lymphoid organs [spleen and cutaneous lymph-nodes (CLNs)] (Supplementary Figures S1A,B) and non-lymphoid tissues (lungs, liver, and skin) (Supplementary Figures S1C-E). To define DC cell populations, we applied gating strategies adapted from (41). As a control Cre-driver line, we used the $C l e c 9 a^{C r e}$ mice (21) bred to Rosa26 $6^{\text {tdRFP }}$. Regardless of the tissues examined, we found that all three mouse models achieved effective targeting of the cDC1-lineage, with $\mathrm{Xcr} 1^{\mathrm{Cre}}$, and $\mathrm{Clec} 9 a^{\mathrm{Cre}}$ being the most efficient (Figure 2). In contrary to $\mathrm{Clec} 9 a^{\mathrm{Cre}}$, the $\mathrm{Xcrl}^{\mathrm{Cre}}$ and $\mathrm{Karma}{ }^{\mathrm{Cre}}$ mouse models did not show any significant Cre activity, neither in pDCs nor in macrophages (Figure 2). However, Cre recombination (tdRFP signal) was detected in a fraction of other cell types. In $\mathrm{Xcr}^{\mathrm{Cre} / w t}$; Rosa2 $6^{\mathrm{tdRFP} / w t}$ mice, a minute proportion $(<1 \%)$ of $\mathrm{CD}^{+} \mathrm{T}$ cells expressed tdRFP in the spleen, CLNs, lung and liver, which increased to a much higher fraction of $\mathrm{CD} 4^{+}$ $\mathrm{T}$ cells in the skin $(8.4 \pm 6.4 \%)$. The $\mathrm{CD} 4^{+} \mathrm{T}$ cells harboring Xcr1-driven Cre recombination lacked detectable level of XCR1 (Supplementary Figure S1E, bottom). Hence, they likely derived from progenitors cells that transiently expressed Xcr1. In the skin, lungs and CLNs of Karma ${ }^{\mathrm{Cre} / w t}$; Rosa26 $6^{\mathrm{tRFP} / w t}$ mice, a fraction of $\mathrm{CDC} 2$ had undergone recombination, although to a lesser extent than in $\mathrm{Clec} 9 a^{\mathrm{Cre} / w t}$; Rosa2 ${ }^{\text {tdRFP/wt }}$ mice where cDC2 were targeted in all tissues (Figure 2). Surprisingly, in the skin of KarmaCre/wt; Rosa26 $6^{\text {tdRFP/wt }}$ mice, a large proportion of mast cells $(61.1 \pm 12.8 \%)$ also expressed the tdRFP (Figure 2).

To further assess cDC1-targeting specificity in the three Cre-driver mouse strains, we analyzed the proportion of different immune cell types within the tdRFP ${ }^{+}$cells (Figure 3, Supplementary Figure S2). As expected on the basis of previous report (21), other cells than $\mathrm{CDC} 1$, in particular $\mathrm{CDC} 2$ and to some extent pDCs, represented the major fraction of the cells targeted in $\mathrm{Clec} 9 a^{\mathrm{Cre}}$ mice (Figure 3). In contrast, in all examined organs, except for the CLNs, cDC1 represented the major fraction of the cells targeted in $\mathrm{Xcr}^{\mathrm{Cre}}$ mice, $\mathrm{CD}^{+} \mathrm{T}$ cells constituting the second most frequent cell types expressing tdRFP in these organs, and the most frequent in the CLNs. This reflects the higher numbers of $\mathrm{CD} 4^{+} \mathrm{T}$ cells as compared to $\mathrm{cDC1s}$ in all these organs. Finally, $\mathrm{CDC1}$ represented the major fraction of targeted cells in Karma ${ }^{C r e}$ mice in all examined organs, except for the skin where $64.4 \pm 5.8 \%$ of the tdRFP ${ }^{+}$ cells were mast cells (Figure 3). We assessed the expression pattern of the Karma gene in mast cells and compared it to a variety of other immune cell types, using the database from the Immgen consortium. These results revealed that mast cells express similar levels of the Karma gene as CDC1 in all organs examined, trachea, tongue, esophagus, skin, and peritoneal cavity (Supplementary Figure S3), consistent with the efficient genetic tracing of mast cells in the skin of Karma ${ }^{\mathrm{Cre}}$ mice. Altogether, these results show that our novel $\mathrm{Xcr}^{\mathrm{Cre}}$ and $\mathrm{Karma}^{\mathrm{Cre}}$ mouse models constitute the most reliable Cre-driver lines reported to date for selective and efficient in vivo targeting of $\mathrm{CDC1}$, with the $\mathrm{Xcrl}^{\mathrm{Cre}}$ model performing the best. However, it should be noted that a small fraction of $\mathrm{CD} 4^{+} \mathrm{T}$ cells is targeted in $\mathrm{Xcr} 1^{\mathrm{Cre}}$ mice and that mast cells are largely targeted in Karma ${ }^{C r e}$ animals.
A

Xcr1 locus

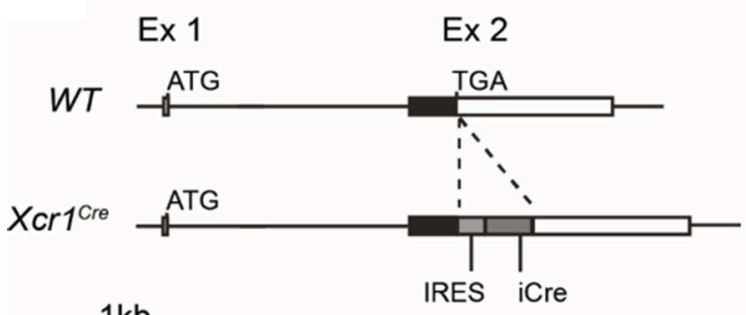

B a530099j19rik (Gpr141b/Karma) locus

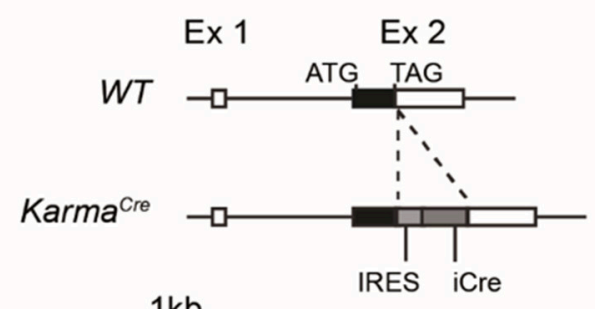

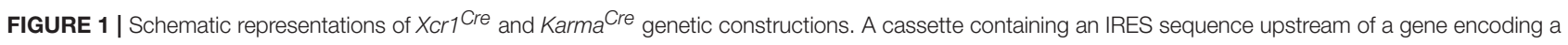
codon-improved CRE recombinase was inserted by homologous ET recombination downstream of the stop codon of $X_{C r} 1$ exon 2 (A) and of a530099j19rik/Karma/Gpr141b exon 2 (B) genes, to produce $\mathrm{Xcr}_{\mathrm{Cr}} \mathrm{Cre}$ and KarmaCre mouse mutants, respectively, on a C57BL/6J background. 


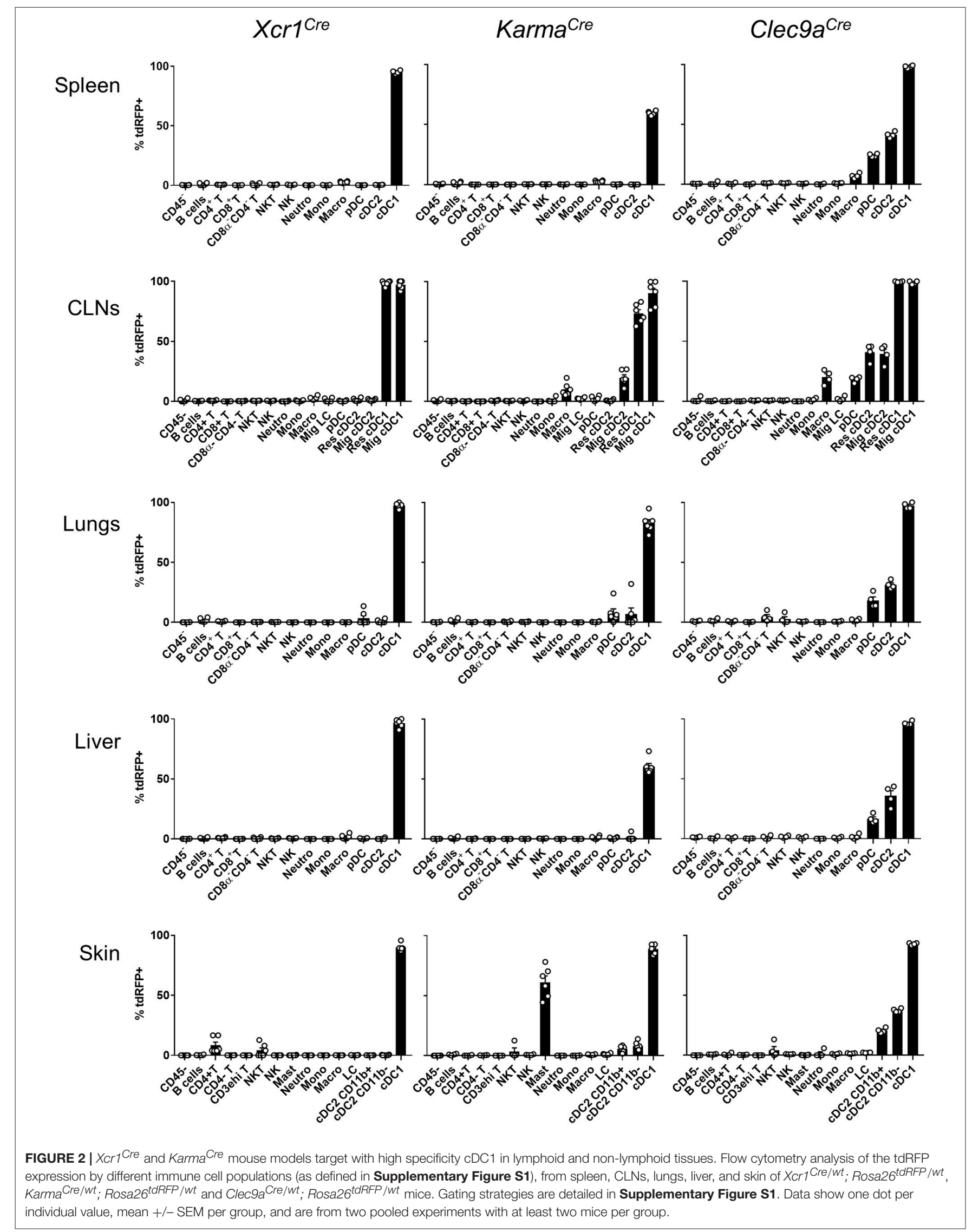


Skin

\section{Xcr1Cre}

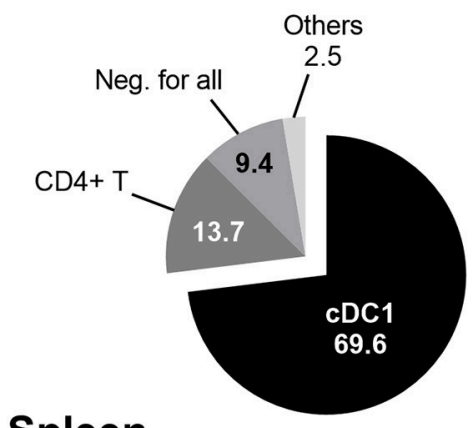

\section{Spleen}
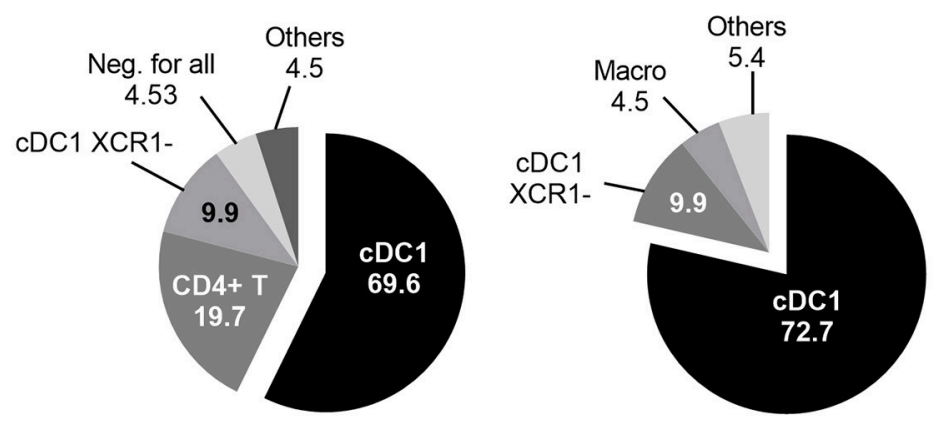

\section{CLNs}
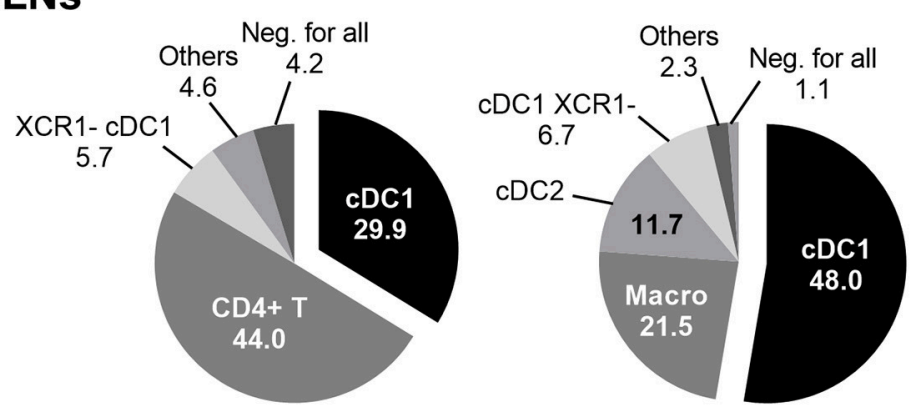

\section{KarmaCre}
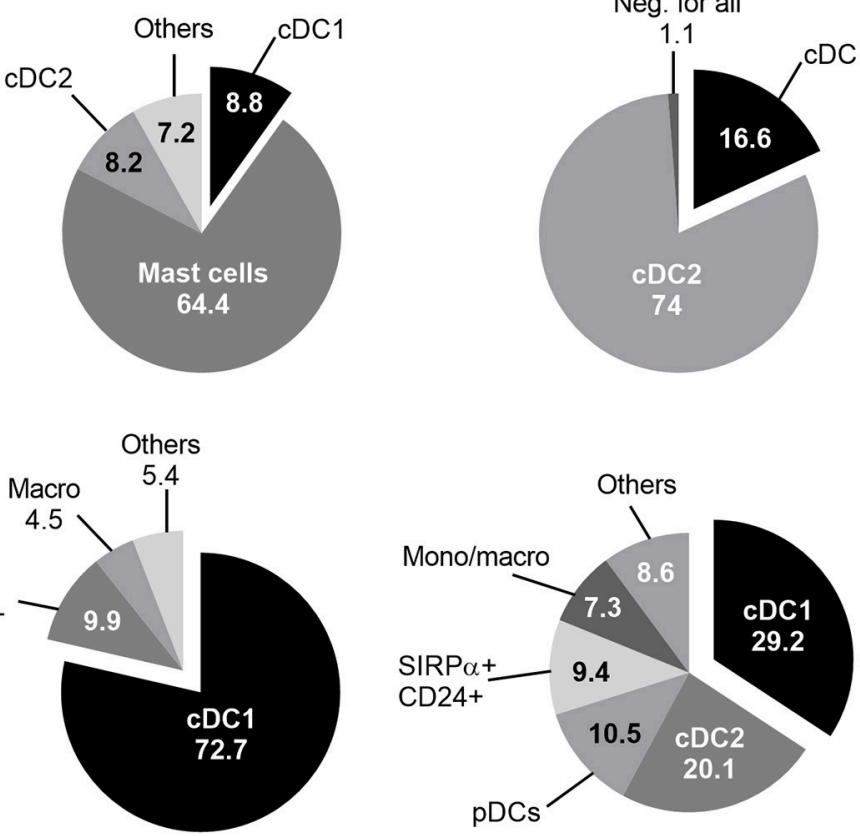

\section{Clec9acre}

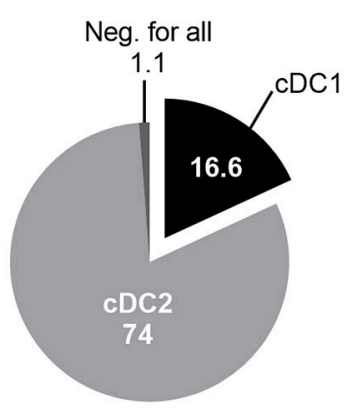

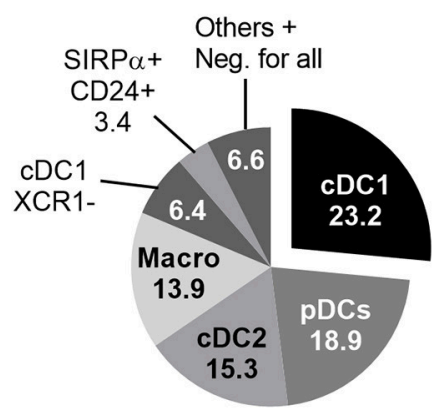

FIGURE 3 | Proportion of cell types within tdRFP ${ }^{+}$cells in the skin, spleen, and CLNs of each genotype. The back gating strategy used to define the relative proportions of cell types among tdRFP ${ }^{+}$cells was performed by using the antibody staining detailed in the upper side of Supplementary Figure S1. Exceptions were made as follow for $X_{C r 1}$ Cre/wt; Rosa26 ${ }^{\text {tdRFP/wt }}$ mice: to define further the tdRFP ${ }^{+}$cells that fell within the Lin $^{+}$(CD19/CD3E/NKp46/Ly6G) gate, the antibody staining detailed in the bottom side of Supplementary Figure $\mathbf{S} 1$ was used. The proportion of CD4 ${ }^{+} \mathrm{T}$ lymphocytes within tdRFP+ cells when using the latter ("lymphoid") antibody panel was matching the proportion of Lin+ cells within tdRFP+ cells when using the former antibody ("myeloid") panel. For KarmaCre/wt;

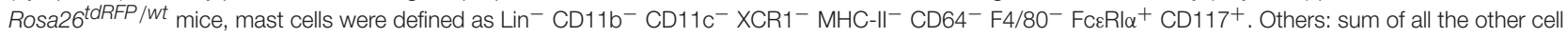
subsets not detailed in the pie charts. Neg. for all, negative for all: cells that did not stain positive for the markers used in the upper antibody panel. Data are shown for one experiment representative of three with three mice per group.

\section{The Use of Different cDC1-Specific Promoters for Driving Cre Expression Reveals Heterogeneity in the CDC1 Population Defined as CD24+ ${ }^{+}$IRP $\alpha^{-}$ cDCs}

To try understanding the lower efficiency of the $\mathrm{Karma}^{\mathrm{Cre}}$ model for $\mathrm{cDC1}$ targeting, as compared to the $\mathrm{Xcr} 1^{\mathrm{Cre}}$ or $\mathrm{Clec} 9 a^{\mathrm{Cre}}$ mice, we examined the expression pattern of the tdRFP reporter within the splenic $\mathrm{cDC} 1$ defined as $\mathrm{CD} 24^{+} \mathrm{SIRP} \alpha^{-}$cDCs (gated in the $\mathrm{CD}_{4} 5^{+} \mathrm{Lin}^{-}$SiglecH ${ }^{-} \mathrm{MerTK}^{-} \mathrm{CD} 64^{-} \mathrm{CD} 11 \mathrm{c}^{+} \mathrm{MHC}-$ $\mathrm{II}^{+} \mathrm{CD} 26^{+}$cells) (13). $\mathrm{CD} 24^{+} \mathrm{SIRP} \alpha^{-}$cDC1 can be split into 4 subsets according to their heterogeneous expression of CD $8 \alpha$ and XCR1 (Figure 4). XCR1 expression was reported to correlate with a better crosspresentation by $\operatorname{cDC} 1(23,42)$. The $\mathrm{CD} 8 \alpha^{+} \mathrm{XCR}^{+}{ }^{+} \mathrm{cDC} 1$ subset was reported to be phenotypically and functionally homogenous $(23,42)$, and likely corresponds to full-fledged differentiated $\mathrm{CDC1}$ endowed with a high 

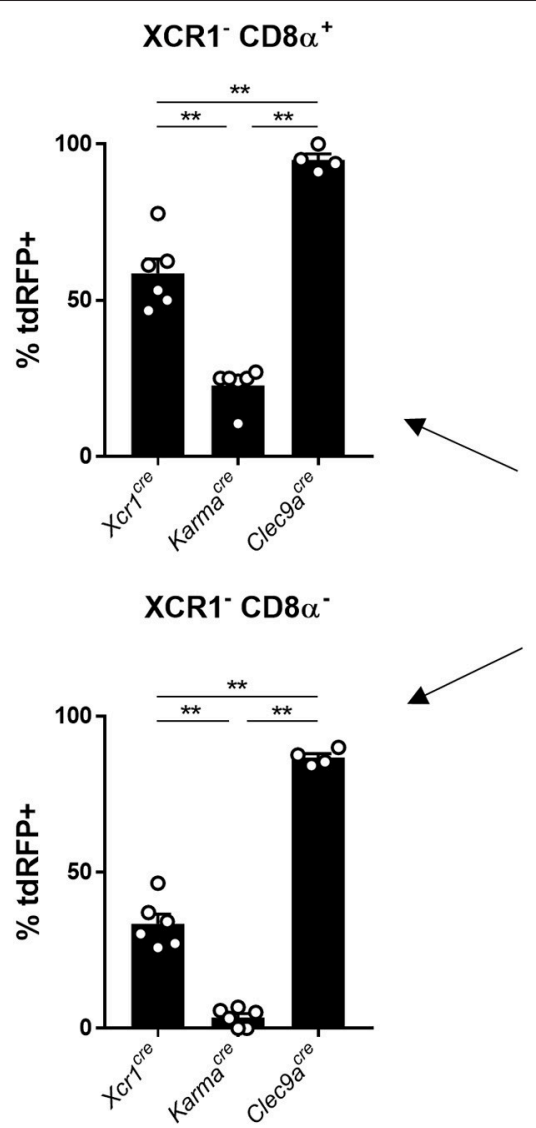

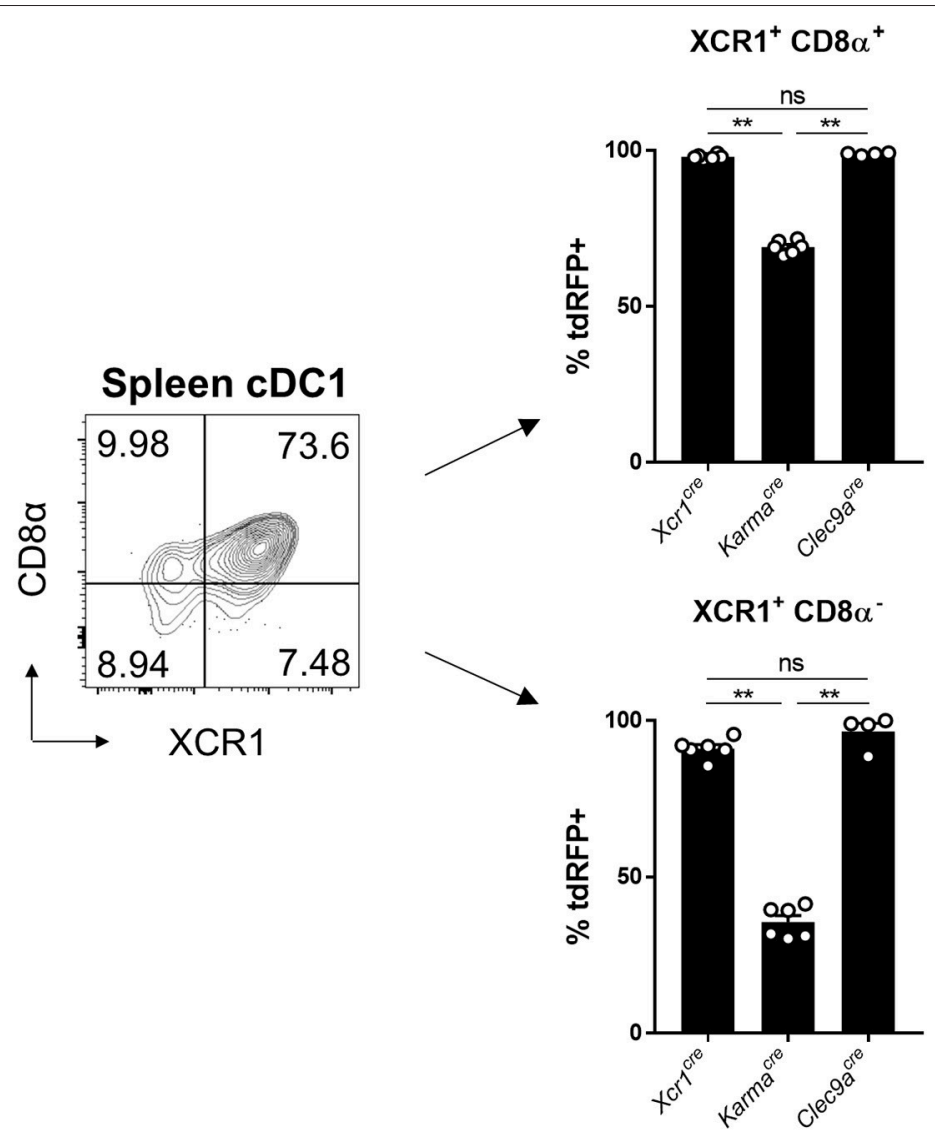

FIGURE 4 | Tracing of $X_{C r} 1$ and Karma expression in the cDC1 population in spleen. Flow cytometry analysis of the tdRFP expression in the 4 CD24 ${ }^{+}$cDC1 subsets

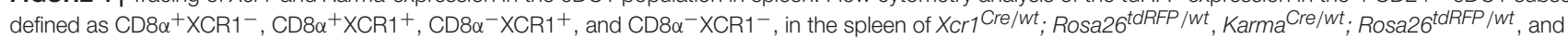
$\mathrm{Clec9a}$ Cre/wt; Rosa26 tdRFP/wt mice. Data show one dot per individual value, mean +/- SEM per group, and are from two pooled experiments with at least two mice per group. Statistical analyses were performed using nonparametric Mann-Whitney tests in all experiments $\left(^{\star \star}, p<0.01 ;\right.$ n.s, non-significant).

crosspresentation activity (43). However, the three other cDC1 subsets, $\mathrm{CD} 8 \alpha^{+} \mathrm{XCR} 1^{-}, \mathrm{CD} 8 \alpha^{-} \mathrm{XCR} 1^{+}$, and $\mathrm{CD} 8 \alpha^{-} \mathrm{XCR} 1^{-}$, have not been extensively characterized. The $\mathrm{CD} 8 \alpha^{-} \mathrm{XCR} 1^{-}$cells may encompass pre-cDC1 $(13,44)$. The $\mathrm{CD} 8 \alpha^{-} \mathrm{XCR} 1^{+}$cells likely correspond to pre-terminally differentiated $\mathrm{cDC} 1$. The $\mathrm{CD} 8 \alpha^{+} \mathrm{XCR}^{-}$cells could correspond to the small fraction of homeostatically matured splenic $\mathrm{CDC} 1$ that have downregulated XCR1 expression, similarly to what occurs at steady state in the skin, the intestine or the thymus $(25,32,39)$. It could also be possible that $\mathrm{XCR} 1^{-}$cells encompass other cell types contaminating the $\mathrm{SIRP} \alpha^{-} \mathrm{CD} 24^{+} \mathrm{CDC} 1$ gate. However, the exclusion of $\mathrm{CD}_{3} \varepsilon^{+}$and $\mathrm{SiglecH}^{+}$cells in our gating strategy ensured that the $\mathrm{CD} 8 \alpha^{+} \mathrm{XCR} 1^{-} \mathrm{CDC} 1$ subset was not contaminated by $\mathrm{CD}^{+} \mathrm{T}$ cells nor $\mathrm{CD} 8 \alpha^{+}$pDCs (45-47). Consistent with the early expression of $\operatorname{Clec} 9 a$ starting at the pre-DC stage (21), Clec $9 a^{C r e}$ model targeted efficiently all 4 subsets, regardless of XCR1 and CD8 $\alpha$ acquisition, with more than $85 \%$ of the cells in each subset expressing tdRFP (Figure 4). Although the $\mathrm{Xcr} 1^{\mathrm{Cre}}$ model was more efficient in targeting $\mathrm{XCR}^{+} \mathrm{CDC} 1$ as initially expected, a significant Cre activity was also detected both in $\mathrm{XCR} 1^{-} \mathrm{CD} 8 \alpha^{-}$and $\mathrm{XCR} 1^{-} \mathrm{CD} 8 \alpha^{+} \mathrm{cDC} 1$ subsets, with $37 \%$ and $53 \%$ of tdRFP expression, respectively (Figure 4). This indicated that a significant proportion of these cells from these two subsets derived from XCR1-expressing precursors, consistent with the hypothesis that they respectively encompass pre-cDC1 and terminally matured cDC1. The KarmaCre model was effective in targeting the $\mathrm{XCR}^{+} \mathrm{CD} 8 \alpha^{+}$ $\mathrm{CDC} 1$ subset, contrasting with no recombination detected in the $\mathrm{XCR} 1^{-} \mathrm{CD} 8 \alpha^{-}$subset and with only a weak Cre activity in the $\mathrm{XCR} 1{ }^{+} \mathrm{CD} 8 \alpha^{-}$subset (Figure 4). The fraction of XCR1 $1^{-} \mathrm{CD} 8 \alpha^{+}$ cDC1 targeted in KarmaCre mice $(22.8 \pm 6.1 \%)$ was lower than that of $\mathrm{XCR} 1{ }^{+} \mathrm{CD} 8 \alpha^{+}{ }^{\mathrm{CDC} 1}(69.0 \pm 2.1 \%)$. This suggest that most of XCR $1^{-} \mathrm{CD} 8 \alpha^{+} \mathrm{CDC} 1$ do not derive from XCR $1^{+} \mathrm{CD} 8 \alpha^{+}$ $\mathrm{CDC1}$ contrary to our expectation that the majority of the former cells correspond to an advanced maturation state of the latter ones. Altogether, the combined use of our fate mapping mouse models suggests consecutive expression of the corresponding genes along the differentiation of the $\mathrm{cDC1}$ lineage in the spleen, with Clec $9 a$ expressed from the common cDC progenitor stage, $X c r 1$ likely starting at the pre-cDC1 stage and Karma turned on only at a later stage similarly to $\mathrm{CD} 8 \alpha$. 


\section{Comparison of the Three Fate Mapping Mouse Strains Advances Our Understanding of the Differentiation Trajectory of CDC1}

We further investigated to which extent our fate mapping mutant mouse models could help refining the differentiation trajectory of $\mathrm{cDC1}$, using as a simple model bone marrow (BM) cells cultured with Fms-like tyrosine kinase 3 ligand (FLT3L) (38). This model allows in vitro generation of three subsets of DCs, which are phenotypically and functionally equivalent to in vivo cDC1 (eq-cDC1), cDC2 (eq-cDC2) and pDCs (eqpDCs) $(38,48-50)$. To refine the differentiation trajectory of $\mathrm{CDC1}$, we followed the acquisition of the tdRFP signal over time in FLT3-L-differentiated DCs generated from BM of our fate mapping mutant mice (Supplementary Figure S4, Figure 5A). $X \mathrm{Cr} 1^{\mathrm{Cre}}$ and $\mathrm{Clec} 9 a^{\mathrm{Cre}}$ models allowed efficient recombination in eq-cDC1 (56 vs. 90\%) (Figure 5A). Interestingly, KarmaCre did not present any recombinase activity in any of the DC populations (Figure 5A). Consistently, whereas gene expression profiling of the eq-DC subsets generated in standard BM FLT3$\mathrm{L}$ cultures confirmed their close homology to their in vivo counterparts isolated from the spleen (Figure 5B), it also showed that eq-cDC1 lacked expression of the Karma, Cd8a and Ly75 (Cd205) genes (Figure 5B, black arrows). This was confirmed using our previously published Karma reporter mouse model knocked-in for tdTomato in the $3^{\prime} \mathrm{UTR}$ of the Karma gene (33) (Supplementary Figure S5A). However, these eq-cDC1 acquired Karma and $\mathrm{CD} 8 \alpha$ expression upon in vivo transfer (Supplementary Figures S5B,C). Karma was also expressed in eq-cDC1 differentiated from BM cells cultured with FLT3-L on feeder cells expressing the Notch ligand Delta-like 1 (Figure 5C, black arrows), similarly to what has been recently reported for CD8 $\alpha$ and CD205 expression (43). Altogether, these results demonstrate a sequential expression of Clec $9 a, X c r 1$ and Karma during cDC1 ontogeny, with Clec9a being induced early starting at the common $\mathrm{CDC}$ progenitor stage (21), then followed by $X c r 1$ which induction might be initiated already at the pre-cDC1 stage. Likewise to $\mathrm{CD} 8 \alpha$, Karma is acquired at a more advanced differentiation stage that is not reached under classical conditions of DC differentiation from BM in FLT3-L in vitro cultures but can be promoted by Notch signaling. This work thus significantly extends two recent studies showing that $\mathrm{CDC} 1$ derived in vitro from mouse or human hematopoietic precursors with a combination of cytokines and growth factors need additional signals to reach a terminal state of differentiation including acquisition of CD8 $\alpha$ expression for mouse $\operatorname{cDC} 1(43,51)$.

\section{The Cre Expression Under Xcr1 or Karma Promoters Remains cDC1-Specific Upon Infection-Induced Inflammation}

The expression of many membrane proteins or transcription factors changes upon inflammation $(12,52)$. An important incentive for generating $\mathrm{Xcr} 1^{\mathrm{Cre}}$ and $\mathrm{Karma}^{\mathrm{Cre}}$ models, was that the expression of the Xcrl and Karma genes was specific for $\mathrm{cDC} 1$ both at steady state and under inflammatory conditions (53). To confirm this observation based on transcriptomic studies, we examined cDC1-targeting specificity of the KarmaCre and $X c r 1^{\text {Cre }}$ mouse models in an inflammatory context, namely systemic mouse cytomegalovirus (MCMV) infection, using the Rosa26 $6^{t d R F P}$ reporter as a read out. We adapted a gating strategy adapted from (52) to identify inflammatory DCs (InflDCs) in spleen and liver (Supplementary Figure S6). Although we could observe the appearance of InflDCs upon MCMV infection, tdRFP expression remained unchanged in infected animals as compared to control mice, being still essentially confined to the $\mathrm{cDC1}$ population, both in $\mathrm{Xcr} 1^{\mathrm{Cre} / w t} ; \operatorname{Rosa} 26^{t d R F P} / w t$ and Karma ${ }^{\mathrm{Cre} / w t} ; \operatorname{Rosa}_{2} 6^{t \mathrm{RFP} / w t}$ mice (Supplementary Figure 6). This demonstrated that both $\mathrm{cDC} 1$-targeting models are stable and allow excision of a floxed genomic sequence efficiently and largely selectively in $\mathrm{CDC} 1$ at steady state and upon inflammation.

\section{Germline Recombination of loxP Sequences Is Frequent in the Offspring of Xcr1 ${ }^{\text {Cre }}$ but Not Karma ${ }^{\text {Cre }}$ Mice}

Recombination of loxP-flanked genomic sequences in germ cells have been described in many Cre mouse models (54-56). To test whether germline recombination occurs in our cDC1-targeting Cre-driver lines, we backcrossed Xcr $1^{\mathrm{Cre} / w t} ; \mathrm{Rosa}_{2} 6^{\mathrm{tdRFP} / w t}$ and KarmaCre/wt ; Rosa26 $6^{t d R F P / w t}$ mice to C57BL/6J mice, and analyzed their offspring for ubiquitous tdRFP expression, using blood $\mathrm{T}$ and $\mathrm{B}$ cells as a readout (Figure 7A). Total or partial germline recombination of the Rosa $26^{t d R F P}$ locus occurred in $95 \%$ of the offspring who had inherited one loxP-flanked allele from $X c r 1^{\text {Cre } / w t}$; Rosa $26^{t d R F P / w t}$ male mice (Figure 7B). Germline recombination occurred with the same frequency irrespective of the segregation of the paternal Cre and loxPflanked alleles in the offspring, demonstrating that this process occurred during meiosis rather than in the embryo. No germline recombination was observed when both alleles were from maternal germ cells (Figure 7B). In ongoing crosses using the $X c r 1^{\text {Cre }}$ mouse model with different loxP-flanked mouse strains, we could also observe germline recombination in the progeny even when the floxed alleles were brought together with the $X c r 1^{C r e}$ allele by the maternal gamete (data not shown). This indicates that, contrary to what the results of the Rosa26 tdRFP/wt backcross appears to suggest, off-target activity of the Cre recombinase in germline is not a gender effect. Additionally, the incidence of germline recombination depended on the loxPflanked allele (data not shown). No occurrence of germline recombination was detected so far for the KarmaCre model (Figure 7B). Therefore, the KarmaCre model might be more appropriate than the $X c r 1^{C r e}$ model to obtain rapidly mice in which $\mathrm{cDC1}$ are inactivated for candidate genes, through conventional breeding strategies. Germline recombination in the offspring should however always be assessed for any novel loxP-flanked allele.

\section{DISCUSSION}

Xcr1 and A530099j19rik (Karma/Gpr141b) genes code for the chemokine receptor XCR1 and for the putative G proteincoupled receptor Gpr141b, respectively, and are among the core 
A

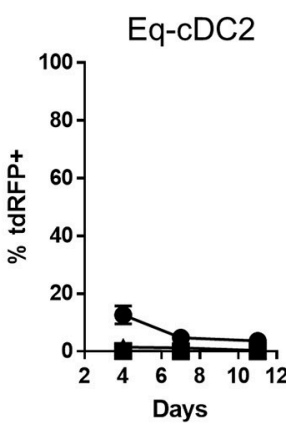

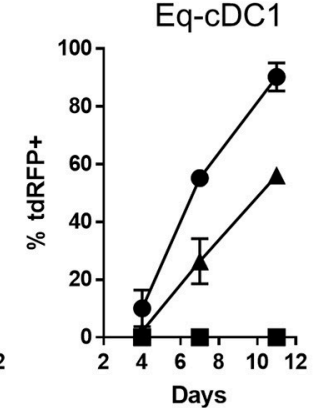

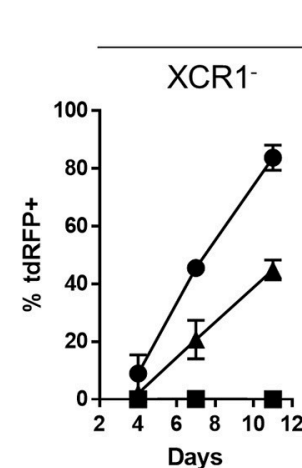

Eq-cDC1

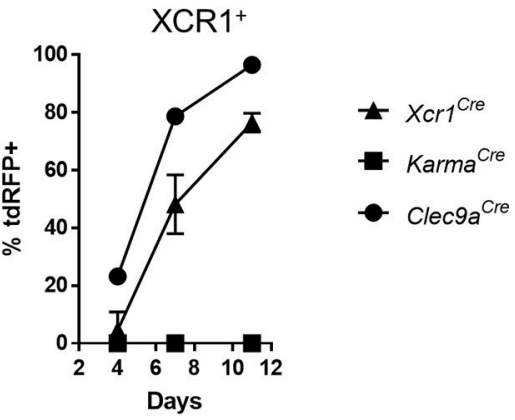

B
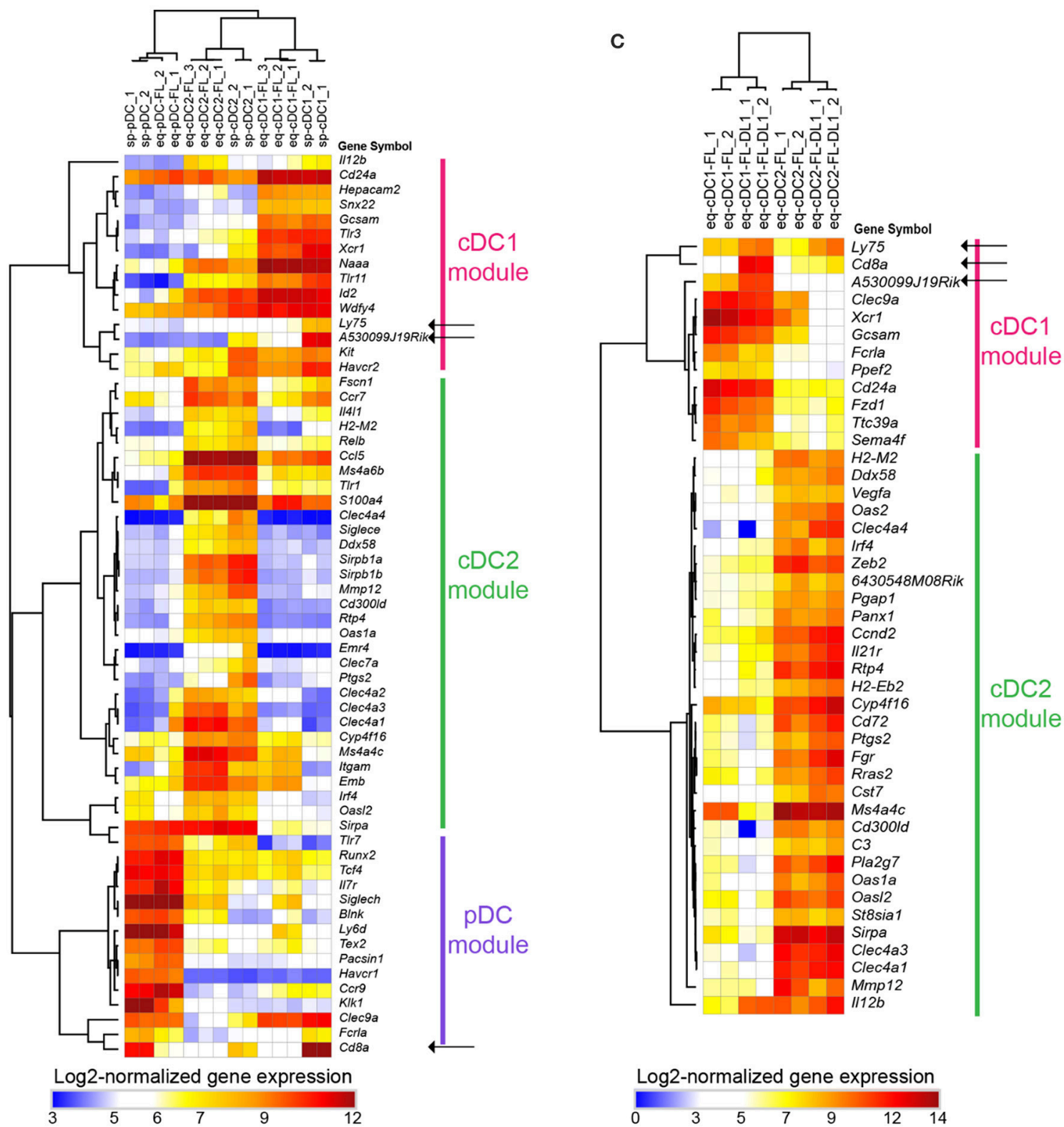

Log2-normalized gene expression

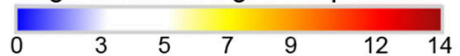

FIGURE 5 | Sequential regulation of Clec9a, XCr1 and Karma expression during CDC1 differentiation. (A) Kinetic analysis of the tdRFP expression in DCs differentiated

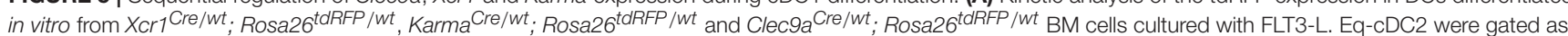


FIGURE 5 | CD11 $\mathrm{C}^{+} \mathrm{MHC}-\|^{+} \mathrm{CD} 24-\mathrm{SIRP} \alpha^{+}$cells, and eq-CDC1 as CD11c+ MHC- $\|^{+} \mathrm{CD} 24^{+} \mathrm{SIRP} \alpha^{-}$cells (Supplementay Figure S4). Data are shown for one experiment representative of two, with three mice per group. (B,C) Heatmaps display the expression profiles of archetypical genes previously shown to be selectively expressed in $\mathrm{cDC1}$, $\mathrm{cDC} 2$, or pDC. (B) Gene expression across $\mathrm{DC}$ types either isolated from murine spleens (sp-pDC, sp-cDC1, and sp-cDC2), or derived in vitro in standard FLT3-L BM cultures (eq-pDC-FL, eq-CDC1-FL, and eq-CDC2-FL), as assessed with microarrays. (C) Gene expression patterns across cDC types derived in vitro from FLT3-L BM cultures under standard conditions (-FL) or on DL1-expression OP9 feeder cells (-FL-DL1), as assessed from public RNA-seq data (GEO accession number GSE110577).

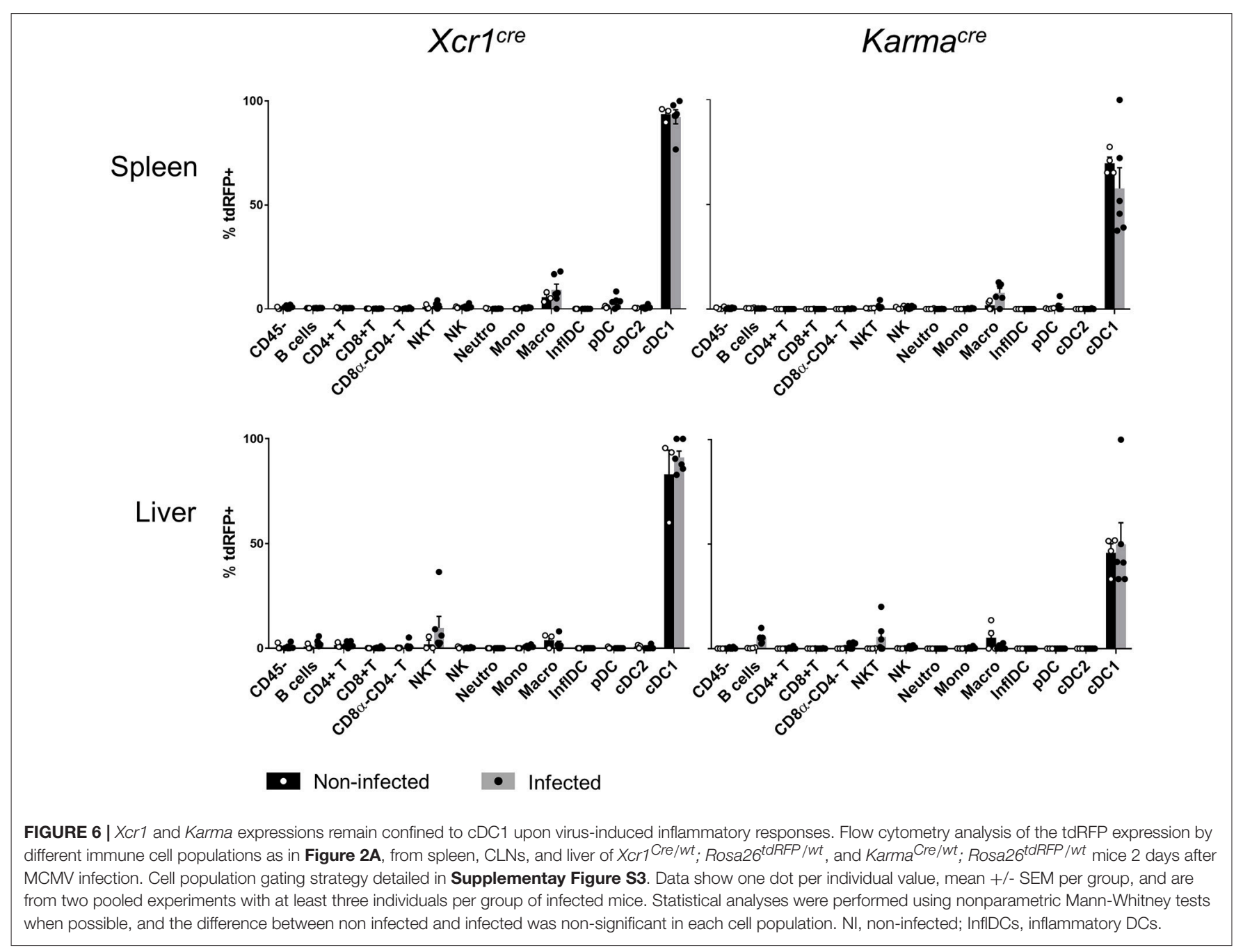

gene signature specifically identifying mouse $\mathrm{CDC1}$ throughout the organism $(10,22-25,33)$. We have inserted an IRES-Cre cassette into the $3^{\prime}$ UTR of the Xcr1 and Karma coding exon to generate $\mathrm{Xcr}^{\mathrm{Cre}}$ and $\mathrm{Karma}{ }^{\mathrm{Cre}}$ mouse models, respectively. In this study, we have characterized the efficiency and specificity of Cre-mediated recombination in these novel mouse models at steady state and upon viral infection, comparing them to the Clec $9 a^{\text {Cre }}$ model. To the best of our knowledge, this study demonstrated that our novel $\mathrm{Xcrl}^{\mathrm{Cre}}$ and $\mathrm{Karma}^{\mathrm{Cre}}$ mouse models are the most trustful and robust for the genetic tracking and manipulation of $\mathrm{CDC} 1$ in vivo.

Amongst the three Cre-driver mouse models examined, $\mathrm{Xcrl}^{\mathrm{Cre}}$ model is the most efficient and specific for fate mapping all $\mathrm{CDC1}$ regardless of the tissues examined. The
Karma ${ }^{C r e}$ model is rather specific for $\mathrm{CDC1}$ when compared with $\mathrm{Clec} 9 a^{\text {Cre }}$ mouse, but much less efficient than the $\mathrm{Xcr}^{\mathrm{Cre}}$ model. Unexpectedly, a fraction of $\mathrm{CD}^{+} \mathrm{T}$ cells is labeled with tdRFP in the $\mathrm{Xcrl}^{\mathrm{Cre}} ;$ Rosa26 $6^{\text {tdRFP/wt }}$ mouse (Figure 2) without expressing any detectable XCR1 at their cell surface (Supplementary Figure S1E). Further analysis need to be conducted to determine whether XCR1 was transiently turned on in the distant progenitors of these cells or on the contrary during their terminal differentiation. Interestingly, the proportion of $\mathrm{Xcr}^{\text {cre }}$ fate-mapped $\mathrm{CD} 4^{+} \mathrm{T}$ cells was much higher in the skin than in the other organs examined, suggesting that these cells may be polarized toward specific functions and/or develop under instructive signals encountered preferentially in barrier organs. Further studies will be needed to test these hypotheses. In the 
A

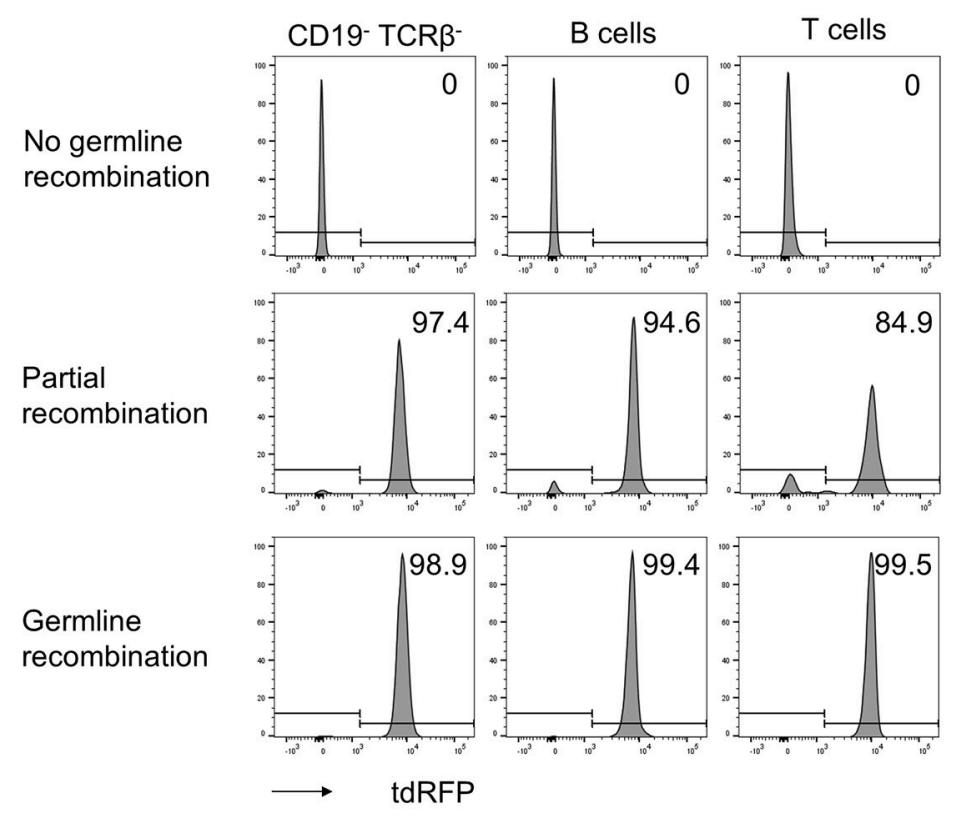

B Germline recombination
$\square$ No germline recombination
Partial recombination

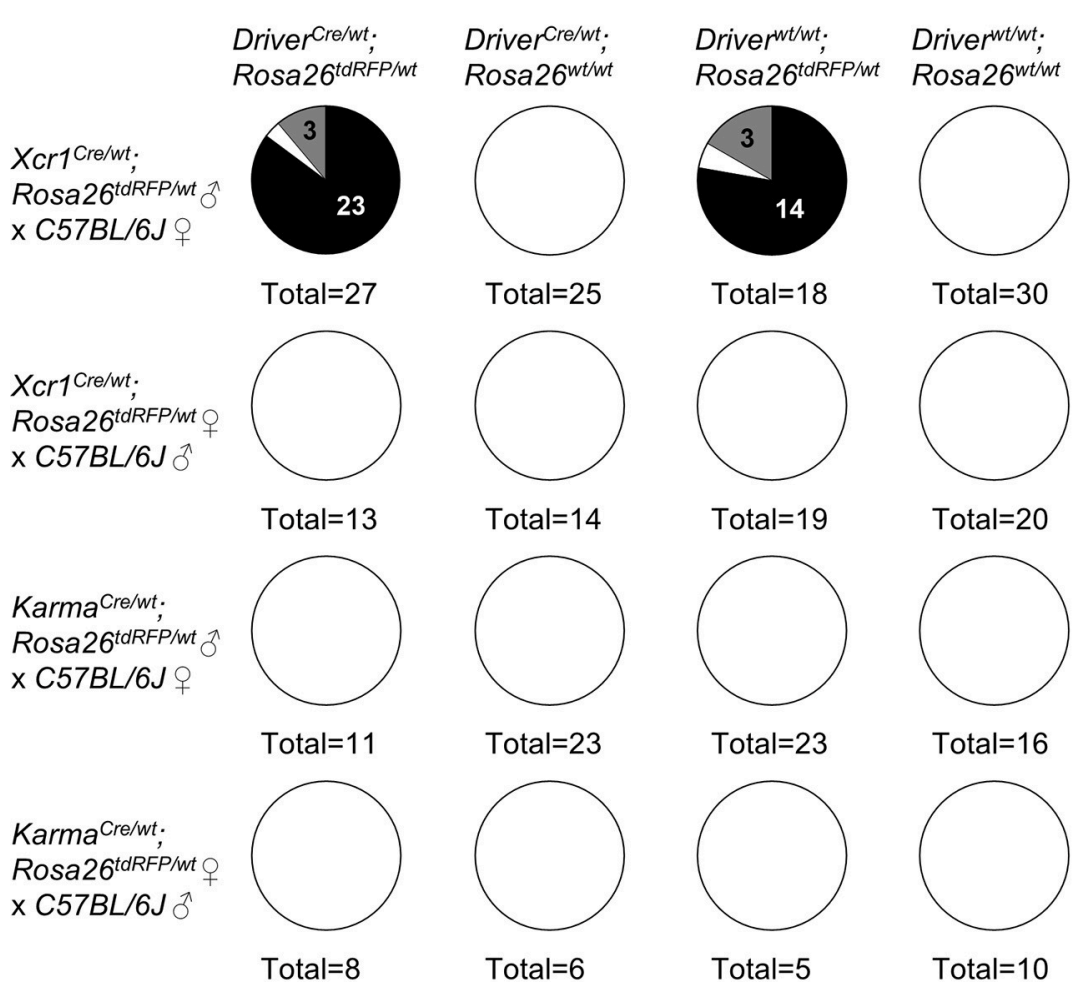

FIGURE 7 | The Cre expression under Xcr1 but not Karma promoter efficiently recombines Lox-sequences in germ cells. (A) Representative flow cytometry analysis of tdRFP expression in CD19- TCR $\beta^{-}$, B and T cells in blood of mice with no germline recombination, partial recombination, and germline recombination. One sample representative of each is shown. (B) Analysis of germline recombination in offspring from backcrosses of $X_{c r 1}$ Cre/wt; Rosa26 tdRFP/wt and KarmaCre/wt;

Rosa26 $6^{t d R F P / w t}$ mice of both sexes with wild-type (WT; C57BL/6J) mice. Germline recombination shown here occurred when both Cre and floxed alleles were of paternal origin. However, with other type of flox constructs, we regularly observed occurrences of germline recombination when both alleles were brought together, either by the father or by the mother. 
skin of the KarmaCre; Rosa26 $6^{t d R F P / w t}$ mouse model, the vast majority of the tdRFP ${ }^{+}$cells were of mast cell origin (Figure 3B). Microarray data released recently by the Immgen consortium (https://www.immgen.org) show that mast cells from the skin, peritoneal cavity, trachea and esophagus express high level of the Karma gene (Supplementary Figure S3), confirming our observation. To the best of our knowledge, this is the first report of a gene that is selectively shared by both $\mathrm{cDC1}$ and mast cells. The KarmaCre mice will therefore be of special interest to researchers aiming at genetically manipulating mast cells in tissues. In all tissues and in all mouse models examined, no tdRFP expression was detected in the CD45-negative cells present in cell suspensions (Figure 2). Although, we did not examine tdRFP expression in other non-hematopoietic cells, it is unlikely that some of these cell types would be targeted in $\mathrm{Xcrl}{ }^{\mathrm{Cre}}$ or $\mathrm{Karma}^{\mathrm{Cre}}$ mice considering that the Xcrl and Gp141b genes were not expressed outside of the hematopoietic system in all of the transcriptomic databases we queried.

To inactivate specifically a candidate gene in $\mathrm{cDC1}$, both alleles of this candidate gene should be excised. This requires a breeding strategy in which one Cre allele and one floxed allele of the gene to be inactivated are brought by the same germ cells, where unexpected recombination could occur. We have tested the frequency of germline recombination for both the $\mathrm{Xcr} 1^{\mathrm{Cre}}$ and Karma ${ }^{\mathrm{Cre}}$ models. Only the $\mathrm{Xcr} 1^{\mathrm{Cre}}$ model showed adventitious Cre activity in germ cells resulting in progeny with recombined Rosa26 $6^{\text {tdRFP }}$ locus in all their cells. Interestingly, this was paternal inherited in this specific experimental setting. However, this may depend on the loxP-flanked construct, as we had events of germline recombination transmitted by females for other floxed genes than the Rosa $26^{\text {tdRFP }}$ reporter. Therefore, to reach specific recombination in $\mathrm{cDC1}$ using the $X c r 1^{\text {Cre }}$ model, the Cre allele and the loxP-flanked allele should be inherited from different parents. We recommend breeding one parent homozygous for both the Cre allele and a null allele of the target gene, to another parent homozygous for the floxed allele of the target gene. Each investigator using the $\mathrm{Xcr} 1^{\mathrm{Cre}}$ model should always test their progeny for unexpected off-target recombination. A recent publication strongly suggested to include, in each experimental procedure of publication using Cre mouse models, detailed procedures about the breeding strategies used and the method the investigators applied to detect any unexpected and unspecific recombination (56).

Our genetic tracing of $\mathrm{CDC} 1$ in vivo in the spleen (Figure 4), or in vitro in FLT3-L-differentiated BM-DC cultures (Figure 5A) revealed heterogeneity in the $\mathrm{CDC1}$ population. The differential expression of Xcr1 and Karma genes within the $\mathrm{CDC} 1$ population qualifies $\mathrm{Xcrl}^{\mathrm{Cre}}$ and $\mathrm{Karma}{ }^{\mathrm{Cre}}$ mouse models as powerful tools to describe further these $\mathrm{CDC} 1$ subsets in vivo. In vitro, BMDCs derived from KarmaCre mice did not show any sign of Cre activity (Figure 5A), confirming that the Karma gene is not transcriptionally active in these cells as directly assessed through their gene expression profiling (Figure 5B), akin to Cd8a or $L y 75$ (Dec205) (43). We show here that expression of the Karma gene on $\mathrm{CDC} 1$ requires accessory signals, which can be provided upon in vivo transfer, or in vitro by Notch signaling likewise to what has been recently reported for $C d 8 a$ and $L y 75$ (43). Of note, in FLT3-L in vitro BM-DC culture, detection in eq-cDC1 of the activity of the Cre recombinase as readout by tdRFP expression seemed to be delayed over time as compared to cell surface acquisition of XCR1 (Figure 5), although the Cre and Xcr1 genes were expressed under the same promoter from one bi-cistronic mRNA. This might be explained by a delayed translation of the Cre gene as compared to $X c r 1$, or because efficient recombination of DNA by the Cre requires time. This latter case might especially apply to the Rosa26 $6^{t d R F P}$ reporter mouse line used in this study, because it was engineered as requiring two consecutive rounds of Cre-excision to generate detectable tdRFP signal, in order to limit any leaky transcription of the fluorescent reporter gene across the stopper at steady state (35). This contrasts to most reporter lines which require only one sequence of recombination to emit signal $(57,58)$ and must therefore require lower and/or less sustained Cre activity to allow recombination. Breeding the $X \mathrm{cr} 1^{\mathrm{Cre}}$ model with a Cre-reporter mouse which is easily recombined (57) might allow a better synchronization of XCR1 surface expression with Cre activity.

Our results advanced our understanding of the differentiation trajectory of $\mathrm{cDC1}$, and validated the $\mathrm{Xcr} 1^{\mathrm{Cre}}$ mouse model as a robust tool to inactivate genes selectively in $\mathrm{CDC} 1$ either in vivo or in vitro using BM-derived DC cultures. Future use of these mutant mouse models will undoubtedly boost the advancing of our understanding of the biology of $\mathrm{cDC} 1$.

\section{AUTHOR CONTRIBUTIONS}

$\mathrm{MD}$ and KC: Conceptualization. RM, CW, BM, MD, and KC: Methodology, Validation, Formal Analysis. RM, CW, SG, MA, $\mathrm{YA}, \mathrm{CS}$, and $\mathrm{AF}$ : Investigation. T-PV, MD: bioinformatics analyses. BM: Mouse model construction supervision. RM, KC: Visualization. RM, KC, and MD: Writing. All authors: Editing. BM, MD, and KC: Project Supervision and Administration.

\section{FUNDING}

This work was in part carried out in the frame of the Innate Immunocytes in Health and Disease (I2HD) collaborative project between CIML, AVIESAN, and SANOFI. It was supported by grants from the European Research Council under the European Community's Seventh Framework Program [FP7/2007-2013 grant agreement number 281225 to M. Dalod; FP7/2007-2013 grant no. 322465 (Integrate) to BM], from the Agence Nationale de la Recherche (ANR; XCR1-DirectingCells to KC), from the Fondation pour la Recherche Médicale (label Equipe FRM 2011, project number DEQ20110421284 to MD), which supported the Karma ${ }^{C r e}$ mouse generation, from the Program Hubert Curien (PHC) Maïmonide-Israel 2017 project number 38155SJ (to MD) supported by the French Ministries of Foreign Affairs (MAEDI) and of Research and Higher Education (MENESR) and from the Fondation ARC pour la recherche sur le cancer (to KC). CIPHE is supported by the French Ministry of Research via PHENOMIN (French National Infrastructure for 
mouse Phenogenomics; ANR10-INBS-07 to BM). This work also benefited from institutional funding from CNRS and INSERM. $\mathrm{RM}$ was supported by doctoral fellowships from the Biotrail $\mathrm{PhD}$ program (Fondation $\left.A^{*} \mathrm{MIDEX}\right)$. RM, CW, SG, and YA were supported by fellowships from Fondation ARC pour la recherche sur le cancer.

\section{ACKNOWLEDGMENTS}

We thank Frédéric Fiore and members of the Centre d'Immunophénomique (CIPHE) (Aix Marseille Univ, INSERM US012, CNRS UMS3367, Marseille, France) for generating the $\mathrm{Xcr} 1^{\mathrm{Cre}}$ and $\mathrm{Karma}{ }^{\mathrm{Cre}}$ mice, and for taking

\section{REFERENCES}

1. Jung S, Unutmaz D, Wong P, Sano G-I, De los Santos K, Sparwasser T, et al. In vivo depletion of $\mathrm{CD} 11 \mathrm{c}+$ dendritic cells abrogates priming of CD8+ $\mathrm{T}$ cells by exogenous cell-associated antigens. Immunity (2002) 17:211-20. doi: 10.1016/S1074-7613(02)00365-5

2. Caton ML, Smith-Raska MR, Reizis B. Notch-RBP-J signaling controls the homeostasis of CD8 - dendritic cells in the spleen. J Exp Med. (2007) 204:1653-64. doi: 10.1084/jem.20062648

3. Stranges PB, Watson J, Cooper CJ, Choisy-Rossi C-M, Stonebraker AC, Beighton RA, et al. Elimination of antigen-presenting cells and autoreactive $\mathrm{T}$ cells by fas contributes to prevention of autoimmunity. Immunity (2007) 26:629-41. doi: 10.1016/j.immuni.2007.03.016

4. Meredith MM, Liu K, Darrasse-Jeze G, Kamphorst AO, Schreiber HA, Guermonprez P, et al. Expression of the zinc finger transcription factor zDC (Zbtb46, Btbd4) defines the classical dendritic cell lineage. J Exp Med. (2012) 209:1153-65. doi: 10.1084/jem.20112675

5. Loschko J, Schreiber HA, Rieke GJ, Esterházy D, Meredith MM, Pedicord $\mathrm{VA}$, et al. Absence of MHC class II on cDCs results in microbialdependent intestinal inflammation. J Exp Med. (2016) 213:517-34. doi: 10.1084 /jem.20160062

6. Satpathy AT, Kc W, Albring JC, Edelson BT, Kretzer NM, Bhattacharya D, et al. Zbtb46 expression distinguishes classical dendritic cells and their committed progenitors from other immune lineages. J Exp Med. (2012) 209:1135-152. doi: $10.1084 /$ jem. 20120030

7. Hildner K, Edelson BT, Purtha WE, Diamond M, Matsushita H, Kohyama $\mathrm{M}$, et al. Batf3 deficiency reveals a critical role for CD8 $\alpha+$ dendritic cells in cytotoxic T cell immunity. Science (2008) 322:1097-100. doi: $10.1126 /$ science.1164206

8. Luda KM, Joeris T, Persson EK, Rivollier A, Demiri M, Sitnik KM, et al. IRF8 transcription-factor-dependent classical dendritic cells are essential for intestinal $\mathrm{T}$ cell homeostasis. Immunity (2016) 44:860-74. doi: 10.1016/j.immuni.2016.02.008

9. Lee W, Kim HS, Hwang SS, Lee GR. The transcription factor Batf3 inhibits the differentiation of regulatory T cells in the periphery. Exp Mol Med. (2017) 49:e393. doi: 10.1038/emm.2017.157

10. Robbins SH, Walzer T, Dembélé D, Thibault C, Defays A, Bessou G, et al. Novel insights into the relationships between dendritic cell subsets in human and mouse revealed by genome-wide expression profiling. Genome Biol. (2008) 9:R17. doi: 10.1186/gb-2008-9-1-r17

11. Sichien D, Scott CL, Martens L, Vanderkerken M, Van Gassen S, Plantinga M, et al. IRF8 transcription factor controls survival and function of terminally differentiated conventional and plasmacytoid dendritic cells, respectively. Immunity (2016) 45:626-40. doi: 10.1016/j.immuni.2016.08.013

12. Tussiwand R, Lee W-L, Murphy TL, Mashayekhi M, Kc W, Albring JC, et al. Compensatory dendritic cell development mediated by BATF-IRF interactions. Nature (2012) 490:502-7. doi: 10.1038/nature 11531 care of mouse breeding; Marilyn Boyron, the cytometry core, and animal house facilities (CIML, UMR7280, France) for critical technical assistance. The authors also thank Rebecca Gentek (Aix Marseille Univ, CNRS, INSERM, CIML, France) for helpful discussion and protocol sharing. This work benefited from data assembled by the ImmGen consortium.

\section{SUPPLEMENTARY MATERIAL}

The Supplementary Material for this article can be found online at: https://www.frontiersin.org/articles/10.3389/fimmu. 2018.02805/full\#supplementary-material

13. Grajales-Reyes GE, Iwata A, Albring J, Wu X, Tussiwand R, Kc W, et al. Batf3 maintains autoactivation of Irf8 for commitment of a CD8 $\alpha(+)$ conventional DC clonogenic progenitor. Nat Immunol. (2015) 16:708-17. doi: 10.1038/ni.3197

14. Lahoud MH, Proietto AI, Gartlan KH, Kitsoulis S, Curtis J, Wettenhall $\mathrm{J}$, et al. Signal regulatory protein molecules are differentially expressed by CD8- dendritic cells. J Immunol. (2006) 177:372-82. doi: 10.4049/jimmunol.177.1.372

15. Merad M, Sathe P, Helft J, Miller J, Mortha A. The dendritic cell lineage: ontogeny and function of dendritic cells and their subsets in the steady state and the inflamed setting. Annu Rev Immunol. (2013) 31:563-604. doi: 10.1146/annurev-immunol-020711-074950

16. Sancho D, Joffre OP, Keller AM, Rogers NC, Martínez D, Hernanz-Falcón P, et al. Identification of a dendritic cell receptor that couples sensing of necrosis to immunity. Nature (2009) 458:899-903. doi: 10.1038/nature07750

17. Caminschi I, Proietto AI, Ahmet F, Kitsoulis S, Shin Teh J, Lo JCY, et al. The dendritic cell subtype-restricted C-type lectin Clec9A is a target for vaccine enhancement. Blood (2008) 112:3264-73. doi: 10.1182/blood-2008-05-155176

18. Huysamen C, Willment JA, Dennehy KM, Brown GD. CLEC9A is a novel activation C-type lectin-like receptor expressed on $\mathrm{BDCA} 3+$ dendritic cells and a subset of monocytes. J Biol Chem. (2008) 283:16693-701. doi: 10.1074/jbc.M709923200

19. Poulin LF, Reyal Y, Uronen-Hansson H, Schraml BU, Sancho D, Murphy KM, et al. DNGR-1 is a specific and universal marker of mouse and human Batf3dependent dendritic cells in lymphoid and nonlymphoid tissues. Blood (2012) 119:6052-62. doi: 10.1182/blood-2012-01-406967

20. Sancho D, Mourão-Sá D, Joffre OP, Schulz O, Rogers NC, Pennington DJ, et al. Tumor therapy in mice via antigen targeting to a novel, DC-restricted C-type lectin. J Clin Invest. (2008) 2098-110. doi: 10.1172/JCI34584

21. Schraml BU, van Blijswijk J, Zelenay S, Whitney PG, Filby A, Acton SE, et al. Genetic tracing via DNGR-1 expression history defines dendritic cells as a hematopoietic lineage. Cell (2013) 154:843-58. doi: 10.1016/j.cell.2013.07.014

22. Bachem A, Güttler S, Hartung E, Ebstein F, Schaefer M, Tannert A, et al. Superior antigen cross-presentation and XCR1 expression define human CD11c + CD141 + cells as homologues of mouse CD8 ${ }^{+}$dendritic cells. $J$ Exp Med. (2010) 207:1273-81. doi: 10.1084/jem.20100348

23. Bachem A, Hartung E, Güttler S, Mora A, Zhou X, Hegemann A, et al. Expression of XCR1 characterizes the Batf3-dependent lineage of dendritic cells capable of antigen cross-presentation. Front Immunol. (2012) 3:214. doi: 10.3389/fimmu.2012.00214

24. Crozat K, Guiton R, Contreras V, Feuillet V, Dutertre C-A, Ventre E, et al. The $\mathrm{XC}$ chemokine receptor 1 is a conserved selective marker of mammalian cells homologous to mouse CD8 $\alpha^{+}$dendritic cells. J Exp Med. (2010) 207:1283-92. doi: $10.1084 /$ jem.20100223

25. Crozat K, Tamoutounour S, Vu Manh T-P, Fossum E, Luche H, Ardouin L, et al. Cutting edge: expression of XCR1 defines mouse lymphoid-tissue resident and migratory dendritic cells of the CD8 + Type. J Immunol. (2011) 187:4411-5. doi: 10.4049/jimmunol.1101717 
26. Dorner BG, Dorner MB, Zhou X, Opitz C, Mora A, Güttler S, et al. Selective expression of the chemokine receptor XCR1 on cross-presenting dendritic cells determines cooperation with CD8+ T Cells. Immunity (2009) 31:823-33. doi: 10.1016/j.immuni.2009.08.027

27. Vu Manh T-P, Elhmouzi-Younes J, Urien C, Ruscanu S, Jouneau L, Bourge $\mathrm{M}$, et al. Defining mononuclear phagocyte subset homology across several distant warm-blooded vertebrates through comparative transcriptomics. Front Immunol. (2015) 6:299. doi: 10.3389/fimmu.2015.00299

28. Bottcher JP, Bonavita E, Chakravarty P, Blees H, Cabeza-Cabrerizo M, Sammicheli S, et al. NK cells stimulate recruitment of $\mathrm{cDC} 1$ into the tumor microenvironment promoting cancer immune control. Cell (2018) 172:102237 e14. doi: 10.1016/j.cell.2018.01.004

29. Brewitz A, Eickhoff S, Dahling S, Quast T, Bedoui S, Kroczek RA, et al. CD8 $+\mathrm{T}$ cells orchestrate pDC-XCR1+ dendritic cell spatial and functional cooperativity to optimize priming. Immunity (2017) 46:205-19. doi: 10.1016/j.immuni.2017.01.003

30. Dorner BG, Smith HRC, French AR, Kim S, Poursine-Laurent J, Beckman $\mathrm{DL}$, et al. Coordinate expression of cytokines and chemokines by NK cells during murine cytomegalovirus infection. J Immunol. (2004) 172:3119-31. doi: 10.4049/jimmunol.172.5.3119

31. Yamazaki C, Miyamoto R, Hoshino K, Fukuda Y, Sasaki I, Saito M, et al. Conservation of a chemokine system, XCR1 and its ligand, XCL1, between human and mice. Biochem Biophys Res Commun. (2010) 397:756-61. doi: 10.1016/j.bbrc.2010.06.029

32. Ohta T, Sugiyama M, Hemmi H, Yamazaki C, Okura S, Sasaki I, et al. Crucial roles of XCR1-expressing dendritic cells and the XCR1-XCL1 chemokine axis in intestinal immune homeostasis. Sci Rep. (2016) 6:23505. doi: 10.1038/srep23505

33. Alexandre YO, Ghilas S, Sanchez C, Le Bon A, Crozat K, Dalod M. XCR1 + dendritic cells promote memory $\mathrm{CD} 8{ }^{+} \mathrm{T}$ cell recall upon secondary infections with Listeria monocytogenes or certain viruses. J Exp Med. (2016) 213:75-92. doi: 10.1084/jem.20142350

34. Shimshek DR, Kim J, Hübner MR, Spergel DJ, Buchholz F, Casanova E, et al. Codon-improved Cre recombinase (iCre) expression in the mouse. Genes (2002) 32:19-26. doi: 10.1002/gene.10023

35. Luche H, Weber O, Nageswara Rao T, Blum C, Fehling HJ. Faithful activation of an extra-bright red fluorescent protein in "knock-in" Cre-reporter mice ideally suited for lineage tracing studies. Eur J Immunol. (2007) 37:43-53. doi: 10.1002/eji.200636745

36. Voehringer D, Liang H-E, Locksley RM. Homeostasis and effector function of lymphopenia-induced "Memory-Like" T cells in constitutively T cell-depleted mice. J Immunol. (2008) 180:4742-53. doi: 10.4049/jimmunol.180.7.4742

37. Gentek R, Ghigo C, Hoeffel G, Bulle MJ, Msallam R, Gautier $\mathrm{G}$, et al. Hemogenic endothelial fate mapping reveals dual developmental origin of mast cells. Immunity (2018) 48:1160-171.e5. doi: 10.1016/j.immuni.2018.04.025

38. Naik SH, Proietto AI, Wilson NS, Dakic A, Schnorrer P, Fuchsberger M, et al. Cutting edge: generation of splenic CD8+ and CD8- dendritic cell equivalents in Fms-like tyrosine kinase 3 ligand bone marrow cultures. J Immunol. (2005) 174:6592-7. doi: 10.4049/jimmunol.174.11.6592

39. Ardouin L, Luche H, Chelbi R, Carpentier S, Shawket A, Montanana Sanchis F, et al. Broad and largely concordant molecular changes characterize tolerogenic and immunogenic dendritic cell maturation in thymus and periphery. Immunity (2016) 45:305-18. doi: 10.1016/j.immuni.2016. 07.019

40. Baranek T, Manh T-PV, Alexandre Y, Maqbool MA, Cabeza JZ, Tomasello E, et al. Differential responses of immune cells to type I interferon contribute to host resistance to viral infection. Cell Host Microbe (2012) 12:571-84. doi: 10.1016/j.chom.2012.09.002

41. Guilliams M, Dutertre C-A, Scott CL, McGovern N, Sichien D, Chakarov S, et al. Unsupervised high-dimensional analysis aligns dendritic cells across tissues and species. Immunity (2016) 45:669-84. doi: 10.1016/j.immuni.2016.08.015

42. Kroczek RA, Henn V. The Role of XCR1 and its ligand XCL1 in antigen crosspresentation by murine and human dendritic cells. Front Immunol. (2012) 3:14. doi: 10.3389/fimmu.2012.00014

43. Kirkling ME, Cytlak U, Lau CM, Lewis KL, Resteu A, KhodadadiJamayran A, et al. Notch signaling facilitates in vitro generation of cross-presenting classical dendritic cells. Cell Rep. (2018) 23:3658-72.e6 doi: 10.1016/j.celrep.2018.05.068

44. Schlitzer A, Sivakamasundari V, Chen J, Sumatoh HRB, Schreuder J, Lum J, et al. Identification of $\mathrm{cDC1}$ - and $\mathrm{cDC} 2$-committed DC progenitors reveals early lineage priming at the common DC progenitor stage in the bone marrow. Nat Immunol. (2015) 16:718-28. doi: 10.1038/ni.3200

45. Bar-On L, Birnberg T, Lewis KL, Edelson BT, Bruder D, Hildner K, et al. CX3CR1+ CD8alpha+ dendritic cells are a steady-state population related to plasmacytoid dendritic cells. Proc Natl Acad Sci USA. (2010) 107:14745-50. doi: $10.1073 /$ pnas. 1001562107

46. Dalod M, Salazar-Mather TP, Malmgaard L, Lewis C, Asselin-Paturel C, Brière $\mathrm{F}$, et al. Interferon alpha/beta and interleukin 12 responses to viral infections: pathways regulating dendritic cell cytokine expression in vivo. J Exp Med. (2002) 195:517-28. doi: 10.1084/jem.20011672

47. O'Keeffe M, Hochrein H, Vremec D, Caminschi I, Miller JL, Anders $\mathrm{EM}$, et al. Mouse plasmacytoid cells: long-lived cells, heterogeneous in surface phenotype and function, that differentiate into CD8 $(+)$ dendritic cells only after microbial stimulus. J Exp Med. (2002) 196:1307-19. doi: $10.1084 /$ jem.20021031

48. Brasel K, De Smedt TD, Smith JL, Maliszewski CR. Generation of murine dendritic cells from flt3-ligand-supplemented bone marrow cultures. Blood (2000) 96:3029-39.

49. Brawand P, Fitzpatrick DR, Greenfield BW, Brasel K, Maliszewski CR, De Smedt T. Murine plasmacytoid pre-dendritic cells generated from Flt3 ligandsupplemented bone marrow cultures are immature APCs. J Immunol. (2002) 169:6711-6719. doi: 10.4049/jimmunol.169.12.6711

50. Gilliet M, Boonstra A, Paturel C, Antonenko S, Xu X-L, Trinchieri G, et al. The development of murine plasmacytoid dendritic cell precursors is differentially regulated by FLT3-ligand and granulocyte/macrophage colony-stimulating factor. J Exp Med. (2002) 195:953-8. doi: 10.1084/jem.20020045

51. Balan S, Arnold-Schrauf C, Abbas A, Couespel N, Savoret J, Imperatore F, et al. Large-scale human dendritic cell differentiation revealing notchdependent lineage bifurcation and heterogeneity. Cell Rep. (2018) 24:190215.e6. doi: 10.1016/j.celrep.2018.07.033

52. Greter M, Helft J, Chow A, Hashimoto D, Mortha A, Agudo-Cantero J, et al. GM-CSF controls nonlymphoid tissue dendritic cell homeostasis but is dispensable for the differentiation of inflammatory dendritic cells. Immunity (2012) 36:1031-1046. doi: 10.1016/j.immuni.2012.03.027

53. Manh T-PV, Alexandre Y, Baranek T, Crozat K, Dalod M. Plasmacytoid, conventional, and monocyte-derived dendritic cells undergo a profound and convergent genetic reprogramming during their maturation. Eur J Immunol. (2013) 43:1706-15. doi: 10.1002/eji.201243106

54. Becher B, Waisman A, Lu L-F. Conditional gene-targeting in mice: problems and solutions. Immunity (2018) 48:835-6. doi: 10.1016/j.immuni.2018. 05.002

55. Schmidt-Supprian M, Rajewsky K. Vagaries of conditional gene targeting. Nat Immunol. (2007) 8:665-68. doi: 10.1038/ni0707-665

56. Song AJ, Palmiter RD. Detecting and avoiding problems when using the Crelox system. Trends Genet. (2018) 34:333-40. doi: 10.1016/j.tig.2017.12.008

57. Liu J, Willet SG, Bankaitis ED, Xu Y, Wright CVE, Gu G. Non-paralle recombination limits cre-loxP-based reporters as precise indicators of conditional genetic manipulation: Cre-Recombinations are Non-Parallel Events. Genesis (2013) 51:436-42. doi: 10.1002/dvg.22384

58. Srinivas S, Watanabe T, Lin C-S, William CM, Tanabe Y, Jessell TM, et al. Cre reporter strains produced by targeted insertion of EYFP and ECFP into the ROSA26 locus. BMC Dev Biol. (2001) 1:4. doi: 10.1186/1471-213X-1-4

Conflict of Interest Statement: The authors declare that the research was conducted in the absence of any commercial or financial relationships that could be construed as a potential conflict of interest.

Copyright (c) 2018 Mattiuz, Wohn, Ghilas, Ambrosini, Alexandre, Sanchez, Fries, Vu Manh, Malissen, Dalod and Crozat. This is an open-access article distributed under the terms of the Creative Commons Attribution License (CC BY). The use, distribution or reproduction in other forums is permitted, provided the original author(s) and the copyright owner(s) are credited and that the original publication in this journal is cited, in accordance with accepted academic practice. No use, distribution or reproduction is permitted which does not comply with these terms. 